\title{
ÆUSGS
}

science for a changing world

\section{Mid-Tertiary Isopach and Lithofacies Maps for the Los Angeles Region, California: Templates for Palinspastic Reconstruction to 17.4 Ma}

Professional Paper 1690

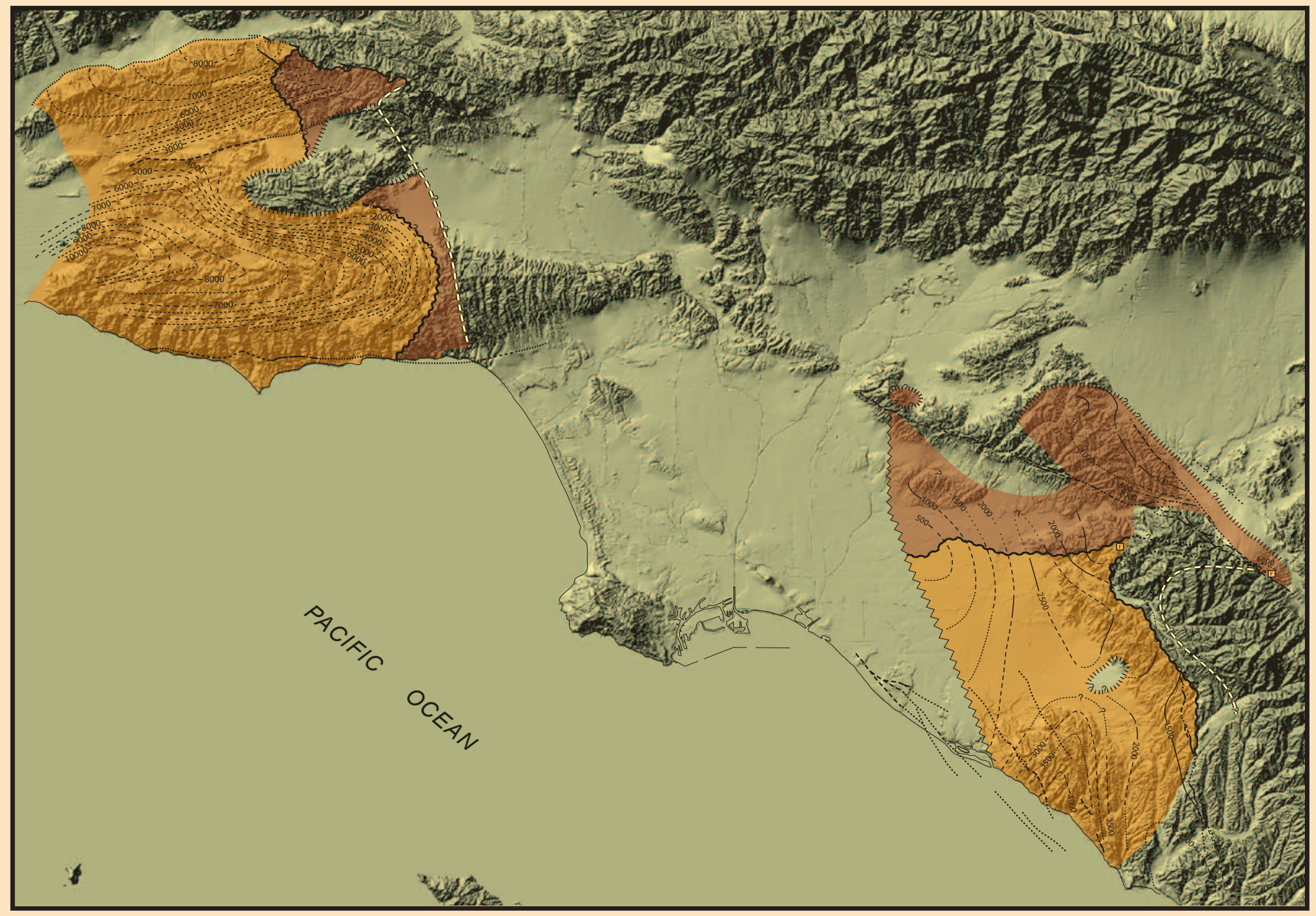

U.S. Department of the Interior U.S. Geological Survey 


\title{
Mid-Tertiary Isopach and Lithofacies Maps for the Los Angeles Region, California: Templates for Palinspastic Reconstruction to 17.4 Ma
}

\author{
By Thane H. McCulloh and Larry A. Beyer
}

A preliminary palinspastic reconstruction is presented of the region of the Los Angeles Basin at its 17.4 Ma inception. To create this reconstruction, pertinent paleomagnetic declination data are combined with new maps of the areal extent, thickness variations, and depositional facies of the >17.4 Ma Sespe-Vaqueros Formations and their equivalents. 


\title{
U.S. Department of the Interior \\ Gale A. Norton, Secretary
}

\author{
U.S. Geological Survey \\ Charles G. Groat, Director
}

Any use of trade, product, or firm names in this publication

is for descriptive purposes only and does not imply endorsement

by the U.S. Government.

United States Government Printing Office: 2004

For additional copies please contact:

USGS Information Services

Box 25286

Denver, CO 80225

This report and any updates to it are available at http://geopubs.wr.usgs.gov/prof-paper/pp1690/

Additional USGS publications can be found at http://geology.usgs.gov/products.html

For more information about the USGS and its products:

Telephone: 1-888-ASK-USGS (1-888-275-8747)

World Wide Web: http://www.usgs.gov/

Text edited by Peter H. Stauffer

Layout and design by Stephen L. Scott

Manuscript approved for publication, October 30, 2003

Cataloging-in-Publication data is on file with the Library of Congress

FRONT COVER

Mapped d

margins of depositional basins of Sespe-Vaqueros Formations draped on a shaded relief map of the study area. Data are adapted from figures 3 and 4 , pages 5 and 6

Dataset (NED). Topography has vertical exaggeration of $x 2$ and sun illumination from azimuth $315^{\circ}$ and elevation $45^{\circ}$. For more information on the NED, see http://gisdata.usgs.gov/ned/. 


\section{CONTENTS}

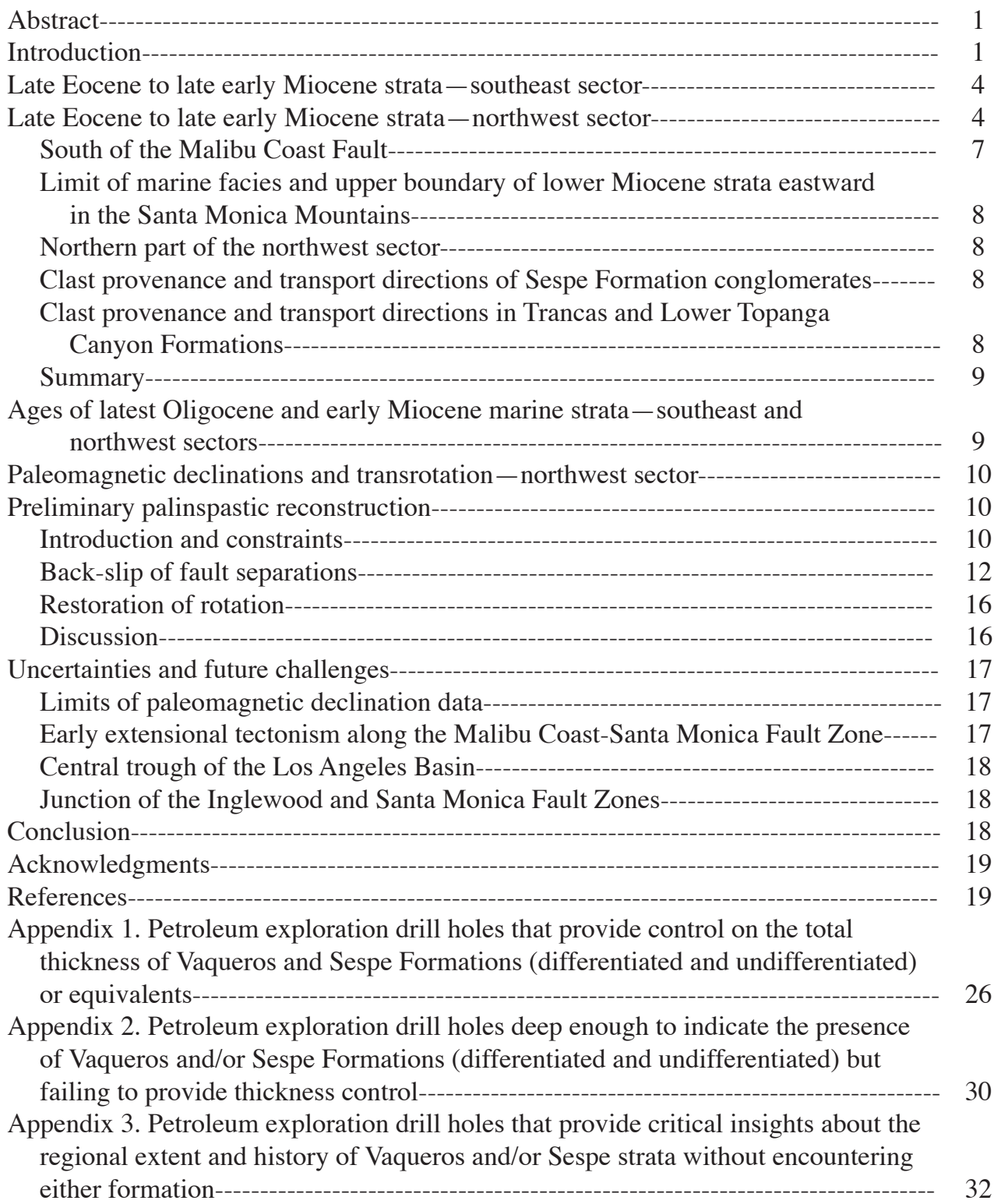

\section{FIGURES}

1. Map of the greater Los Angeles Basin showing major structural elements, faults, and geographic features-------------- 2

2. Chronostratigraphic diagram of time and facies relationships and formation nomenclature for Post-Cretaceous and pre-Pliocene rock units in the principal parts of the Los Angeles Basin region-

3. Map showing outcrops and present (plus restored) surface and subsurface thickness and major facies of the

Sespe plus Vaqueros Formations in the southeast sector-

4. Map showing outcrops and present (plus restored) surface and subsurface thickness and major facies of the Sespe plus Vaqueros and Trancas Formations in the northwest sector-

5. Map of paleomagnetic declinations for the northwest sector, with major faults and selected geographic features------

6. Diagram of major fault separation estimates, noteworthy regionally developed unconformities (or depositional interruptions), and important igneous episodes of the greater Los Angeles region-

7. Preliminary palinspastic reconstruction of the greater Los Angeles Basin region-- 


\section{TABLES}

1. Age, paleomagnetic declinations, basis, and published sources for well documented localities in the northwest sector of the greater Los Angeles Basin region- 



\title{
Mid-Tertiary Isopach and Lithofacies Maps for the Los Angeles Region, California: Templates for Palinspastic Reconstruction to 17.4 Ma
}

\author{
By Thane H. McCulloh' and Larry A. Beyer ${ }^{2}$
}

\section{Abstract}

Opening of the Neogene Los Angeles Basin began abruptly about 17.4 Ma. Extensional rifting, with local basaltic volcanism, began the process and accompanied its early stages. Crustal detachment, followed by clockwise tectonic rotation and translation of large crustal blocks has been shown by previous paleomagnetic declination measurements in the western Transverse Ranges Province northwest of the basin and by large strike-slip and dip-slip separations on several major faults transecting it. Successful palinspastic reconstruction of the region to its arrangement before $17.4 \mathrm{Ma}$ depends on understanding and integration of many stratigraphic and structural components.

Before 17.4 Ma, fluviatile, alluvial and floodplain deposits, interstratified in the younger part with shallow marine to deeper shelf transgressive equivalents, accumulated to thicknesses as great as several kilometers. This report maps the surface and subsurface extents, thickness variations, and facies patterns of these strata, the Sespe plus Vaqueros and Trancas Formations or equivalents. Separate southeast and northwest sectors are revealed, each with distinctive internal thickness and facies patterns, which must have been related before rifting and transrotation. Terrestrial vertebrate and marine molluscan and foraminiferal fossils, plus magnetostratigraphic profiles of other workers and a few dates of igneous rocks, provide timing for key depositional and structural events.

Our preliminary reconstruction of the region brings the internal patterns of the northwest and southeast sectors toward congruity but leaves unsatisfied discrepancies that suggest important information is missing. The reconstruction focuses attention on critical elements, specific uncertainties, and deficiencies of prior reconstructions. It also provides a new foundation for further work.

\section{Introduction}

Conceptual understanding of the origin and evolution of the Los Angeles Basin and its surroundings - shown

17136 Aberdeen Avenue, Dallas, Texas 75230

2U.S. Geological Survey, 345 Middlefield Road, Menlo Park, California 94025 with selected geographic features, faults, and structural elements in figure 1 - began a notable shift following publication of the first paleomagnetic evidence implying regional detachment, translation, and large ("about $70^{\circ}$ ") clockwise steep-axis rotation of the western Santa Monica Mountains since early Miocene time (Kamerling and Luyendyk, 1979). Subsequent studies enlarged the paleomagnetic data base geographically and stratigraphically, made clear that the entire western Transverse Ranges Province (and some contiguous areas including the Channel Islands; see Kamerling and Luyendyk, 1985) have rotated more or less together as a block (Liddicoat, 1990), established that some younger formations record smaller rotations than some older formations (Hornafius and others, 1986), and suggest that declination has changed linearly since about $17 \mathrm{Ma}$ at a rate of about "5.79 degrees/m.y."(Luyendyk, 1990, fig. 3a). Based on the declination data and various assumptions or estimates about strike-slip separations on major to minor zones, at least seven substantially different regional palinspastic reconstructions have been proposed (Hornafius and others, 1986, fig. 9; Wright, 1991, fig. 36; Crouch and Suppe, 1993; Howard and Lowry, 1995; Dickinson, 1996; Bohannon and Geist, 1998; Fritsche, 1998; Ingersoll and Rumelhart, 1999). These models lead to differing paleogeographic reconstructions for the time preceding the onset of transrotation. To gauge the validity of those reconstructions and to improve on them if possible, this report presents quantitative maps of the extent, thickness variations, gross lithofacies distributions, and evidences of age for the nonmarine Eocene-lower Miocene Sespe Formation and the interfingering Oligocene-lower Miocene transgressive marine Vaqueros Formation (and its equivalents) in the Los Angeles Basin region. These presumed prerift and prerotational formations provide the foundation for a new preliminary reconstruction.

Nonmarine clastic strata of late Eocene to late early Miocene age interbedded with partly marine Oligocene to late early Miocene clastic strata are critical to this study and occur in two separate sectors. A southeast sector spans the San Joaquin Hills, northwestern Santa Ana Mountains, eastern portion of the Los Angeles Basin, two areas north of the Whittier fault, and a small area northeast of the Chino and Elsinore Fault Zones (fig. 1). A northwest sector covers the central and western Santa Monica Mountains plus buried and outcropping areas farther north, including the Simi Valley 
and Oakridge uplift to as far as the Oakridge-Santa Susana Fault Zone (fig. 1). Between the two sectors, strata of late Eocene to late early Miocene age are either known to be absent or are buried so deeply that their presence is not demonstrated.

In both sectors, widespread thick nonmarine sandstone, conglomerate, and sandy claystone, with local fanglomerate and fluvial channel fill, are called Sespe Formation. The oldest floodplain and fluvial deposits are late Uintan (middle Eocene), on the basis of land mammal fossils from both sectors (Stock, 1948; Kelly, 1990; Calvano and others, 2003; Whistler and Lander, 2003). The youngest nonmarine strata in the sequence are Oligocene to latest early Miocene. These nonmarine strata are interbedded with or overlain by better sorted and generally finer grained greenish-gray to very dark gray marine sandstones and siltstones of the Vaqueros Formation in parts of both sectors. Such marine strata are abundantly fossiliferous locally, yielding mollusks and, in a few places, foraminifers that are indicative of early Miocene ages (24 to $17.5 \mathrm{Ma}$ ) (Loel and Corey, 1932; Yerkes and Camp- bell, 1979, p. E11; Schoellhamer and others, 1981; Blake, 1983). Nonmarine interbeds and correlative facies, as well as some littoral Vaqueros Formation beds, have yielded land mammal fossils locally that are interpreted to range from early Arikareean (28 Ma) to latest early Hemingfordian (17.5 Ma) in land mammal ages (Lander, 1983; Lucas and others, 1997; Whistler and Lander, 2003). In most of the western Santa Ana Mountains the marine Vaqueros Formation facies and nonmarine Sespe Formation facies are interbedded intimately and have been mapped as "Sespe-Vaqueros undifferentiated" (Woodford and Gander, 1980, fig. 3; Schoellhamer and others, 1981, p. D31).

Internal depositional gaps and unconformities, some of long duration, are recognized within the Sespe and Vaqueros Formations. One spans approximately the period 40-30 Ma and probably is of major regional extent (Minch and others, 1989, fig. 4; Lander, 1994, fig. 2; Prothero and others, 1996, figs. 8 and 9). Another is important in the southeastern sector (Belyea and Minch, 1989, fig. 3; McCulloh and others, 2000, p. 1168; Calvano and others, 2003). Some are minor

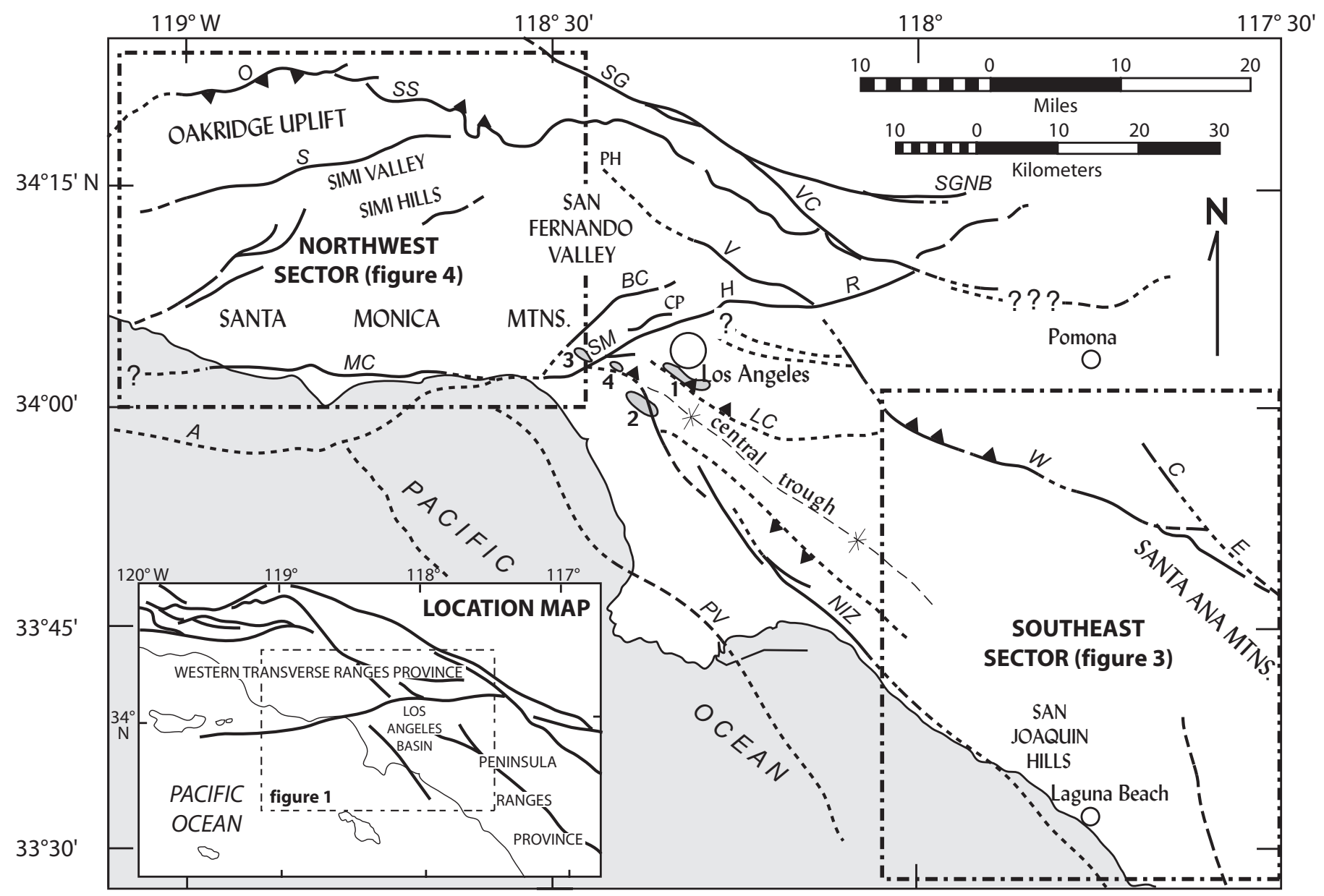

Figure 1.-The greater Los Angeles Basin region, showing major structural elements, faults (dashed or queried where uncertain), geographic features, and frames of subordinate southeast and northwest sectors (figs. 3, 4). Fault abbreviations: A-Anacapa, BC-Benedict Canyon, C-Chino, E-Elsinore, H-Hollywood, LC - Las Cienegas, MC-Malibu Coast, NIZ-Newport-Inglewood zone, 0-0akridge, PV-Palos Verdes, R-Raymond, S-Simi, SG-San Gabriel, SGNB-San Gabriel north branch, SM-Santa Monica, SS-Santa Susana, VC-Vasquez Creek, V-Verdugo, W-Whittier. Geographic abbreviations: CP-Cahuenga Pass, PH—Pacoima Hills. Oil fields: 1—Las Cienegas, 2-Inglewood, 3-Sawtelle, 4-Cheviot Hills. 


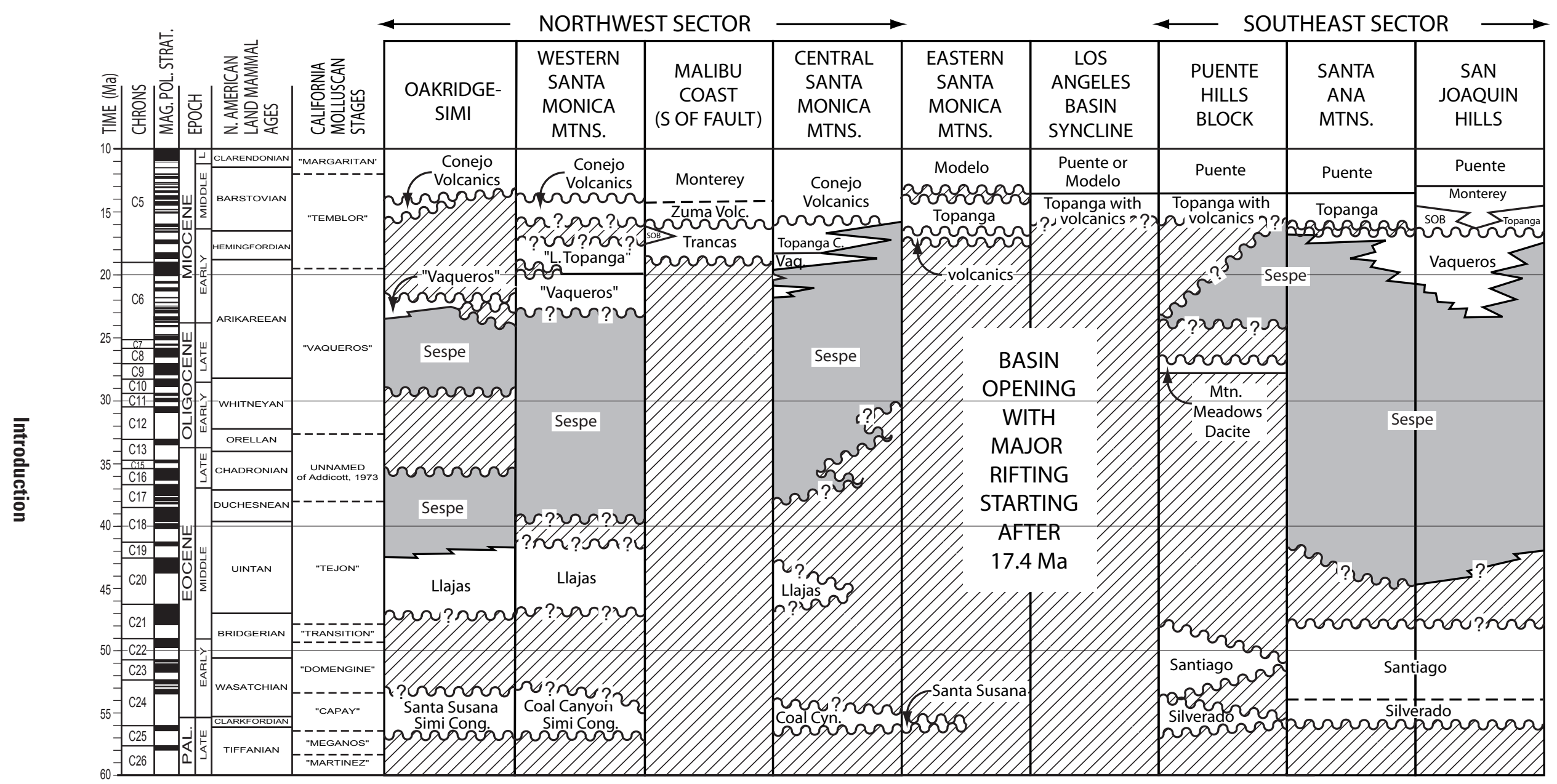

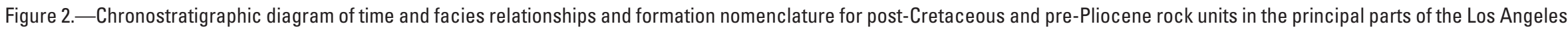

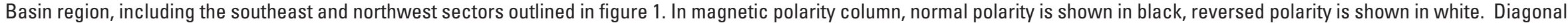
striping indicates absence of section; wavy lines mark unconformities or edges of time gaps. SOB = San Onofre Breccia. 
(Oborne, 1993, fig. 3) or only intimated; many others probably are unrecognized.

Submarine olivine basalt flows rest disconformably on Paleogene strata and unconformably on older rocks in the easternmost Santa Monica Mountains. These oldest of a regionally developed suite of Miocene basic volcanics, dated at 17.4 Ma (McCulloh and others, 2002), offer clues to tectonomagmatic events associated with onset of opening of the Los Angeles Basin and the connected clockwise transrotation of the western Transverse Ranges region. They are presumably the earliest expression of deep crustal magmatism accompanying extensional tectonism and mark the close of a long period of relative crustal stability.

These and other chronostratigraphic specifics and depositional facies variations and gaps are summarized graphically in figure 2. The formational units shown were chosen to emphasize depositional and other events closely preceding 17.4 Ma; scant attention is given to all other events.

\section{Late Eocene to Late Early Miocene Strata-Southeast Sector}

Outcrops of coarse fluviatile conglomerate and interbedded nonmarine arkosic sandstone and mudstone of the Sespe Formation, plus less abundant finer grained silty sandstone of the Vaqueros Formation facies, are exposed principally in the northwestern Santa Ana Mountains and San Joaquin Hills (Vedder and others, 1957; Woodford and Gander, 1980, fig. 3; Schoellhamer and others, 1981; Belyea and Minch, 1989). Limited outcrops of partly correlative nonmarine strata also occur northeast of the Whittier Fault Zone (Durham and Yerkes, 1964), and mostly nonmarine beds crop out northeast of the Chino and Elsinore Fault Zones (Gray, 1961; Schoellhamer and others, 1981). Subsurface Sespe and Vaqueros Formation strata have been sampled from a few dozen deep petroleum exploration drill holes to the north and west of the outcrop areas. The distribution of Sespe and Vaqueros Formation strata is thereby extended over a much larger area than is suggested by the outcrops (Schoellhamer and others, 1981, p. D72-D81; West and Redin, 1991a, 1991b; McCulloh and others, 2001, fig. 5).

Stratal thicknesses of Sespe plus Vaqueros Formations taken from drill holes (appendix 1) have been combined with those measured at outcrops to provide a new map of the distribution and thickness variations of the combined formations (fig. 3).

Edges of the mapped strata result from a combination of postdepositional erosion, depositional limits or basin margins (locally), and lack of subsurface control. Original depositional limits are suggested where the extent of postdepositional erosion can be confidently inferred. Limits caused by erosion are also shown where they are recognized.

Strata north of latitude $33.85^{\circ} \mathrm{N}$ and nearly all strata east of longitude $117.6^{\circ} \mathrm{W}$ are nonmarine fluviatile sandstones and gravels. Strata south of latitude $33.85^{\circ} \mathrm{N}$ are mostly nonmarine also, but with fossiliferous marine interbeds, especially at and near the top of the sequence. To the southwest, in the San Joaquin Hills, a younger Vaqueros Formation is readily distinguishable at mapping scales from an underlying distinctive nonmarine and generally coarser Sespe Formation (Vedder and others, 1957; Woodford and Gander, 1980, fig. 3).

The maximum areal limits of the transgressive marine Vaqueros Formation facies is a proxy for an early Miocene proximal shoreline of the Sespe-Vaqueros Formations of the southeastern section. Our focused fieldwork, together with published data (Vedder and others, 1957; Gray, 1961; Yeats, 1976; Woodford and Gander, 1980, fig. 3; Schoellhamer and others, 1981; Daniel-Lyle, 1995, fig. 6; Howard and Lowry, 1995, fig. 2) define the shoreline in the outcrop areas. Available drill hole samples and records have been analyzed to extend the marine facies and its northern limit westward from the northern Santa Ana Mountains outcrops to the western edge of subsurface control. The resulting newly mapped area of marine facies clearly defines an early Miocene southwestward-opening transgressive marine embayment separated from more northerly and easterly areas of exclusively fluviatile and alluvial deposits, the "Santa Ana Bay" of Loel and Corey (1932) (fig. 3).

The provenance of certain distinctive, locally derived Sespe Formation clasts from both outcrops and drill-hole samples of strata younger than $27 \mathrm{Ma}$ in the northern part of the southeast sector (McCulloh and others, 2001, fig. 6) indicate transport of clasts to the southeast, south, and southwest. Other clasts of nondiagnostic lithologies might also be locally derived, and many others might have been recycled from older local sedimentary units. However, many more distinctive exotic imports carry important paleogeographic implications (Woodford and others, 1968, 1972; Woodford and Gander, 1980; Lane, 1989; Howard, 2000). Evidently most of these imports were transported into the basin from the east or northeast, judging from clast size gradations and paleocurrent indicators (Belyea and Minch, 1989, fig. 5, table 4; Howard and Lowry, 1995, fig. 2).

The isopach contours (fig. 3) define an apparent axis of greatest thickness that trends northeast to northwest and that is nearly orthogonal to the line showing the most northerly extent of marine facies. The Sespe-Vaqueros trend of greatest thickness crudely mimics the underlying north-southtrending Paleocene-early Eocene axis of greatest thickness (McCulloh and others, 2000, fig. 4). Possible implications of the north-trending Sespe-Vaqueros maximum thickness trough and the stratal thinning near the west end of the marine-nonmarine facies line are discussed later.

\section{Late Eocene to Late Early Miocene Strata-Northwest Sector}

Great stratal thicknesses, complex facies relationships, poor exposures in many places, and vexing local structural 

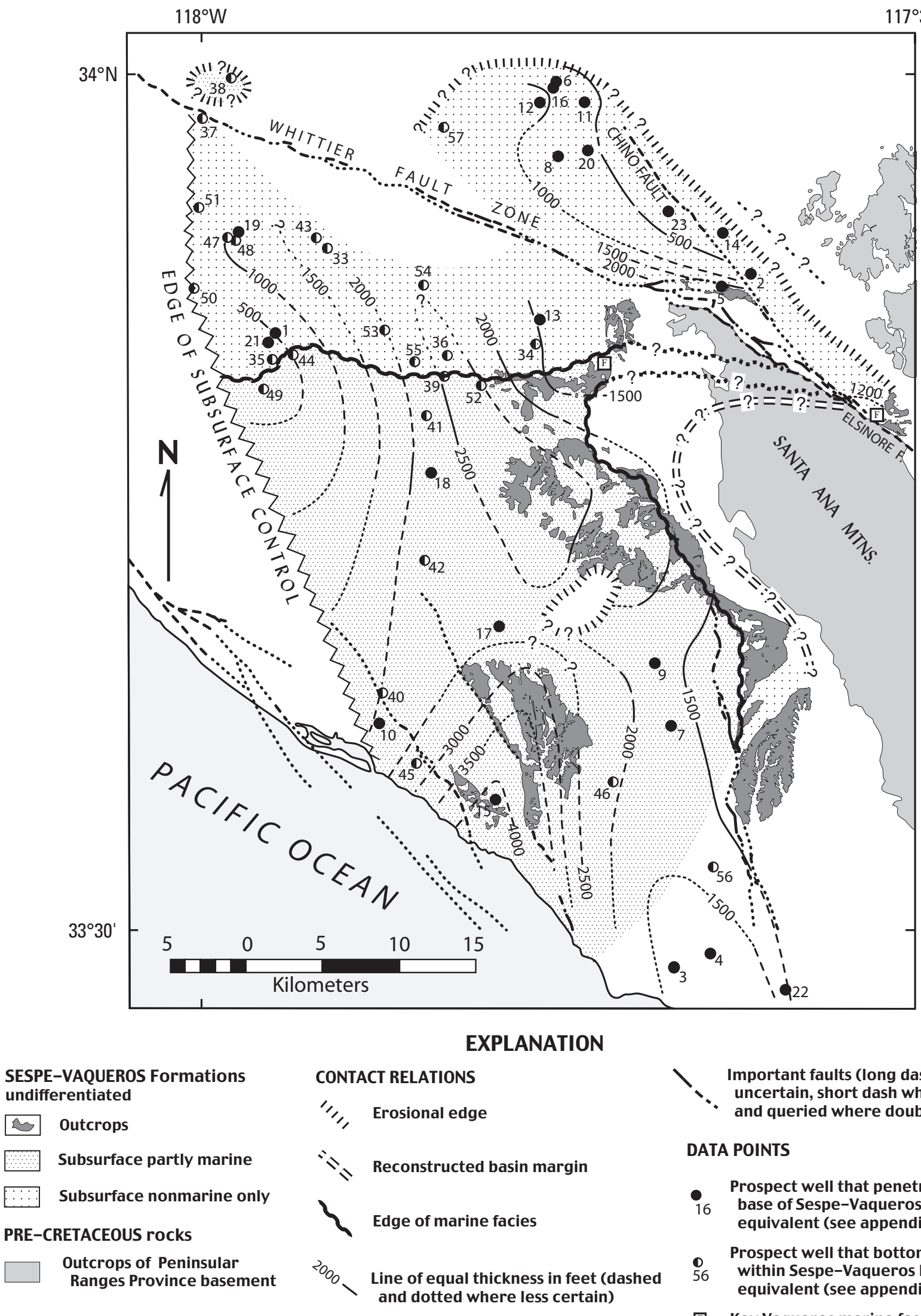
Important faults (long dash where
- uncertain, short dash where inferred, and queried where doubtful).

\section{DATA POINTS}

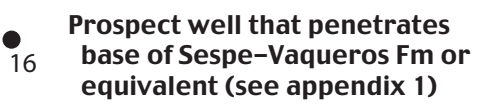

Prospect well that bottoms

56 within Sespe-Vaqueros Fm or equivalent (see appendix 2)

․ Key Vaqueros marine fossil localities

Figure 3.- - Outcrops and present (plus restored) surface and subsurface thickness and major facies of the Sespe plus Vaqueros Formations in the southeast sector. "Reconstructed basin margin" is an estimate of the original extent of Sespe-Vaqueros strata for the depositional system. 
complications of the late Eocene-early Miocene sequence of the central and western Santa Monica Mountains all combine, with some weaknesses in fossil control and innumerable middle Miocene intrusions, to defy simple summary. Our description attempts to make comprehensible a very large and complex mass of structurally disturbed stratified rocks. Our simple model-a single isopach map (fig. 4) - combines the aggregated thicknesses of the late Eocene-early Miocene Sespe Formation, the Oligocene- early Miocene Vaqueros Formation, and the early Miocene parts of the Topanga Canyon Formation of Yerkes and Campbell (1979). The most important prior sources for this model are Arnold (1907, p. 525-526), Kew (1923), Woodford and Bailey (1928), Loel and Corey (1932), Soper (1938), Durrell (1954), Nagle and Parker (1971), Weber and others (1973), Stuart (1976), Vedder and Howell (1976), Truex (1976), Stuart (1979), Yerkes and Campbell (1979), Turner and Campbell (1979), Yerkes and Campbell (1980),

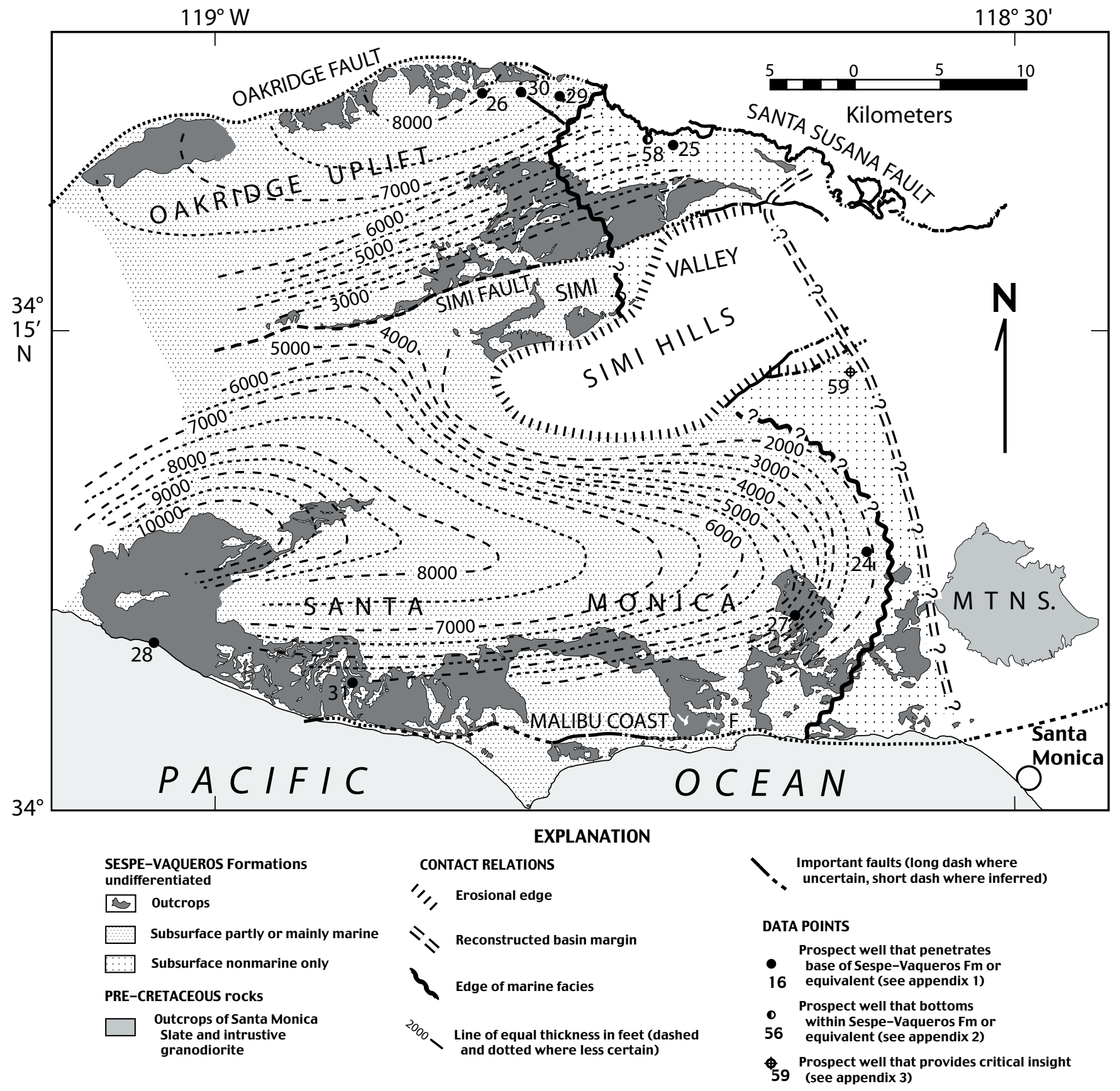

Figure 4.- - Outcrops and present (plus restored) surface and subsurface thickness and major facies of the Sespe plus Vaqueros and Trancas Formations and equivalent units in the northwest sector. "Reconstructed basin margin" is an estimate of the original extent of Sespe-Vaqueros strata for the depositional system. 
Dibblee (1982), Howard (1989), Dibblee and Ehrenspeck (1990), Fritsche (1993), Oborne (1993), and Campbell and others (1996). Our model relies heavily on the published isopach maps of Nagle and Parker (1971, figs. 7 and 8) in the western part of the Santa Monica Mountains and the part of the northwest sector that is west and southwest of the Simi Hills. Sespe Formation and lower Miocene isopach maps of Nagle and Parker (1971) were summed and adjusted to agree with structure sections closely controlled by outcrop geology (Campbell and others, 1996; Dibblee and Ehrenspeck, 1990; Yerkes and Campbell, 1980) and, in a few places, with drill hole control. The model also reflects results of our selective field work plus interpretations of land-mammal fossils from younger parts of the Topanga Canyon Formation in the east-central parts of the mountains (Whistler and Lander, 2003).

The total aggregate thickness of the Sespe, Vaqueros, and the early Miocene part of the Topanga Canyon Formation is conservatively estimated to exceed 2,300 m (7,500 ft) in the west- central Santa Monica Mountains near longitude $118.75^{\circ} \mathrm{W}$, and it might be as much as 3,000 $\mathrm{m}(10,000$ $\mathrm{ft}$ ). This is so despite a prominent erosional unconformity that separates the sequence from the overlying middle Miocene Conejo Volcanics ( $\leq 16.7 \mathrm{Ma}$; Turner and Campbell, 1979, table 1) and another local erosional break within the sequence between the Vaqueros Formation and overlying early Miocene parts of Topanga Canyon Formation strata (Oborne, 1993, fig. 3). The thickness diminishes eastward as the nonmarine Sespe Formation (facies) coarsens and becomes dominant (Yerkes and Campbell, 1979, fig. 3; Fritsche, 1993, fig. 4). Redbeds of the Sespe Formation do not crop out west of about longitude $118.85^{\circ} \mathrm{W}$, but they are present and thick in deep drill holes to and beyond the western edge of our map (Nagle and Parker, 1971, fig. 7; Dibblee and Ehrenspeck, 1990; Campbell and others, 1996; appendix 1). For example, many deep drill holes farther northwest near longitude $119.12^{\circ} \mathrm{W}$ penetrated Sespe Formation that alone ranges up to $1,800 \mathrm{~m}(6,000 \mathrm{ft})$ thick (Nagle and Parker, 1971, fig. 7). We estimate conservatively that the aggregate thickness of the Sespe, Vaqueros, and early Miocene parts of the Topanga Canyon Formations is greater than $3,000 \mathrm{~m}(10,000 \mathrm{ft})$ at the western edge of our map area.

Exposed strata older than Conejo Volcanics are dominantly muddy marine sandstone and siltstone in the western part of the mountains, reflecting the east-to-west transition from largely nonmarine to offshore marine facies during later early Miocene deposition. Dolomitic concretions and beds and thin or lenticular conglomerates are present but rare. Macrofossils occur sparsely, mostly within the sequence mapped as "Vaqueros" (Loel and Corey, 1932; Weber and others, 1973). The overlying Encinal Member of the Topanga Canyon Formation is dark mudstone, interbedded in many places with sandstone and containing dolomitic concretions in its lower parts. On the basis mainly of its microfauna, we agree with Nagle and Parker (1971, fig. 8) and Fritsche (1993, fig. 4) that the Encinal Member (facies) is all early Miocene, older than 16.4 Ma (Barron and Isaacs,
2001, fig. 22.1), although Yerkes and Campbell (1979, p. E16) consider it to be chiefly middle Miocene.

\section{South of the Malibu Coast Fault}

The east-west-trending Malibu Coast Fault Zone bounds the south margin of the Santa Monica Mountains east of a point near longitude $118.94^{\circ} \mathrm{W}$, where it crosses the shoreline. West of that point it continues westward offshore (Junger and Wagner, 1977; Pinter and others, 1998, fig. 1; Seeber and Sorlien, 2000, fig. 1; Sorlien and others, 2000, fig. 1). Sespe Formation and older strata are unknown south of the Malibu Coast Fault Zone. The oldest strata seen there are mostly marine sandstones interbedded with minor mudstone and pebbly sandstone plus distinctive interbedded schist breccia, also called the San Onofre Breccia (Woodford and Bailey, 1928; Stuart, 1976, 1979). This breccia is composed almost entirely of unsorted angular blocks of green schist, glaucophane schist, metagabbroic rocks and related lithologies derived from the distinctive Jurassic Catalina Schist. The Catalina Schist is known to be present in place offshore and onshore to the south and southeast and consists of distinctive oceanic glaucophanebearing schist, greenschists, and related metagabbroic rocks (Schoellhamer and Woodford, 1951; Hill, 1971; Yeats, 1973 , 1974; Sorensen, 1985).

The heterogeneous sedimentary sequence limited to the coastal strip south of the Malibu Coast-Santa Monica Fault Zone and west of Point Dume has been called Trancas Formation (Yerkes and Campbell, 1979, p. E25-E27). It bears some resemblance to parts of the Vaqueros and lower Topanga Canyon Formations exposed north of the offshore projection of the fault zone (Dibblee and Ehrenspeck, 1990) farther west and near Point Mugu. Marine fossils occur but tend to be poorly preserved and long-ranging mollusks. Turritella ocoyana Conrad has been identified and interpreted as "Temblor" provincial molluscan stage early to middle Miocene (Yerkes and Campbell, 1979, p. E27). These strata west of Point Dume are here considered to be early Miocene because they lack clasts of the $<16.7 \mathrm{Ma}$ Conejo and Zuma Volcanics and seem to predate the 17.4 Ma oldest Topanga volcanics (Hoots, 1931) of the eastern Santa Monica Mountains.

The base of the Trancas Formation is not exposed. We and others infer that it rests directly on Catalina Schist without intervening thick Cretaceous, Paleocene, middle Eocene, or Sespe sedimentary units that are present north of the Malibu Coast Fault (Campbell and others, 1966, fig. 3). If this inference is incorrect, another complicated structural arrangement is needed to explain the presence within the Trancas Formation of coarse breccia composed predominantly of large, unworn blocks of Catalina Schist (Stuart, 1976, fig. 6). The Anacapa Fault, which appears to mark the southern edge of the western Transverse Ranges Province (Yerkes and Lee, 1979, p. 34), may or may not have been a factor controlling the deposition of the schist breccia in 
the Trancas Formation. Whatever the case, the age of the youngest Trancas Formation is important for understanding the structural evolution.

\section{Limit of Marine Facies and Upper Boundary of Lower Miocene Strata Eastward in the Santa Monica Mountains}

The easternmost extent of marine strata in the combined Sespe-Vaqueros-Topanga Canyon Formations is a final important element of the Santa Monica Mountains part of the northwestern sector stratigraphy. Most of the marine sequence in the western part of the mountains, the Vaqueros and overlying Topanga Canyon Formations, grades eastward into nonmarine Sespe Formation and its partial equivalent, the nonmarine Fernwood Member of the Topanga Canyon Formation (Yerkes and Campbell, 1980). The easternmost outcrops of Vaqueros Formation are west of longitude $118.56^{\circ} \mathrm{W}$. Land mammal fossils from the Fernwood Member (nonmarine) are "early late Hemingfordian (late early to early middle Miocene)" (Whistler and Lander, 2003) (or 19.0-16.6 Ma), suggesting that the overlying Cold Creek Member (marine) is partly or entirely middle Miocene. Although the lower part of the Cold Creek Member might be equivalent to the uppermost parts of some of the undifferentiated Topanga Canyon Formation west of longitude $118.67^{\circ} \mathrm{W}$, we exclude all of it where it has been separately mapped farther east. Thus the type "Topanga Canyon fauna" (Arnold, 1907; Kew, 1923), long assigned to the "Temblor Stage" of the middle early to middle Miocene and present in the upper part of strata mapped as the Cold Creek Member, is excluded from our maps and correlations. This exclusion does not influence the placement of the easternmost marine facies boundary.

One final point of control is the Atlantic Oil Co. "Nettleship" No. 1 (fig. 4, prospect well No. 24; appendix 1), which penetrated fossiliferous "Vaqueros" and underlying Sespe Formation and bottomed in marine Eocene or older strata (core samples and U. S. Geological Survey file data). These drill hole data, together with outcrop fossil control, support both isopach lines and the location of the line approximating the easternmost extent of marine facies.

\section{Northern Part of the Northwest Sector}

Understanding of the distribution, thickness, and facies of the Sespe and Vaqueros Formations north of the Santa Monica Mountains is partial and uneven. Postdepositional uplift and erosion completely removed evidence in a large area south of the Simi Fault and also limits accurate appraisals in extensive outcrops north of that fault. Despite such limitations, approximate isopachs and an estimate of the reconstructed landward edge of the transgressive marine facies are presented here (fig. 4). These are based importantly on the work of Bailey (1947), Hall and others (1975),
Blake (1983), Blundell (1983), Seedorf (1983), Yeats (1987), and Huftile (1988) and on a few deep drill holes (appendix 1). Combined Sespe and Vaqueros Formation strata in this northern part of the sector are more than 2,400 $\mathrm{m}(8,000 \mathrm{ft})$ thick in the eastern part of a west-trending isopach maximum just south of the Oakridge Fault Zone (Bailey, 1947; Huftile, 1988, p. 125-132). An erosional break between Vaqueros and Sespe strata in part of the area (Huftile, 1988) suggests an originally even greater composite thickness along part of the Oakridge uplift.

\section{Clast Provenance and Transport Directions of Sespe Formation Conglomerates}

Trends of maximum clast size and abundance in Sespe Formation conglomerates of the Santa Monica Mountains and Simi Valley indicate predominantly east-to-west sediment transport, consistent with indications from clast imbrications and trough cross bedding (Howard, 1989, figs. 9, 10; Howard and Lowry, 1995, fig. 2, table 2). Most clasts are compositionally unlike present-day bedrock sources to the east or are nondiagnostic lithologies. Important exceptions include rare anorthosite clasts (unconfirmed by us) reported from the uppermost Sespe Formation of the Simi Hills (Paschall and Off, 1959, p. 6; Paschall and Off, 1961, p. 1953; Taylor, 1984; Lander, 1994, p. 86) and from the lower Miocene Topanga Canyon Formation of the central Santa Monica Mountains (Flack, 1993, p. 67). Probable noteworthy exceptions are the tourmalinized quartz monzonites, quartz diorites, and quartzites reported by R. R. Simonson from the lower Sespe Formation conglomerates of the central Santa Monica Mountains (Soper, 1938, table 1). As described, some of these strongly resemble tourmalinized Mesozoic rocks from the northwestern Peninsular Ranges about 80 miles to the east (Irving, 1937, p. 300). Still other possible exceptions are clasts of nondurable schist, slate, meta-andesite, and metadiabase that resemble bedrock metamorphic rock types of the northern Santa Ana Mountains. Lane (1989), Howard and Lowry (1995, p. 29-32), and Howard (2000) discuss the latter special exceptions and suggest possible sources for such metamorphic clasts and the much more abundant and durable distant imports.

\section{Clast Provenance and Transport Directions in Trancas and Lower Topanga Canyon Formations}

The most noteworthy exception to the overall pattern of sediment transport from east to west for Sespe, Vaqueros, and Topanga Canyon Formations of the Santa Monica Mountains and Simi Valley occurs in the Trancas Formation along the coast west of Point Dume and south of the Malibu Coast Fault and in the lower Topanga Canyon Formation north of the fault east and west of Point Mugu. San Onofre Breccia (Woodford and Bailey, 1928), interbedded 
with arkosic sandstone and muddy siltstone and derived from unique metamorphic sources nearby to the south, was transported northward into the basin along short paths that limited clast rounding or sorting (Stuart, 1976, fig. 6). Occurrences of breccia in the Trancas Formation are prominent at Lechuza Point and intermittently from there along the beach for almost $5 \mathrm{~km}$ (3 miles) to the west (Dibblee and Ehrenspeck, 1990). Glaucophane schist detritus occurs north of the Malibu Coast Fault in Lower Topanga sandstones (Dibblee and Ehrenspeck, 1990) and conglomerates about $14.5 \mathrm{~km}$ (9 miles) westerly from Lechuza Point and also about $1.5 \mathrm{~km}$ (1 mile) west of Point Mugu. This sedimentation probably overlaps the time during which the "Piuma," "Saddle Peak," and parts of the "Fernwood" Members of the Vaqueros-Topanga Canyon Formations (Yerkes and Campbell, 1979, fig. 3; Fritsche, 1993, fig. 4) were being deposited by westward-flowing streams on a floodplain northeast of the Malibu Coast Fault. Multiple but uncommon subrounded clasts of arkose and feldspathic siltstone, one boulder of foraminiferal calcareous siltstone, and multiple but rare subrounded clasts of fossiliferous oyster-bearing sandstone occur among angular blocks of schist at Lechuza Point. These show that at least a thin blanket of sedimentary strata, resembling more durable parts of the Encinal Member of the Topanga Canyon Formation and composed of detritus from granitoid sources, probably covered parts of the Catalina Schist source terrain prior to breccia deposition. The absence of associated clasts of Zuma Volcanics (fig. 2) shows that both the breccias and associated finer grained strata west of Point Dume predate the middle Miocene volcanism instead of being contemporaneous (Yerkes and Campbell, 1979, fig. 5, p. E28). Schistbearing prevolcanic strata from north of the Malibu Coast Fault to the west near Point Mugu were also at least partly derived from the south but are overwhelmingly dominated by sand-size detritus of granitoid derivation, indicating mixed provenance. The easternmost of these occurrences is in the "Lower Topanga" (Dibblee and Ehrenspeck, 1990) probably less than $1,400 \mathrm{~m}$ (4,500 feet) below the base of the Conejo Volcanics about $5 \mathrm{~km}$ (3 miles) east-southeast of Point Mugu. A complex paleogeography, engendered by a complicated prior structural rearrangement, is clearly indicated by these facts and invites more precise dating and further analysis.

\section{Summary}

Noteworthy features of the northwest sector isopachfacies map (fig. 4) are variable and locally large thicknesses, approximate east-west trends of the axes of greatest and least thickness, eastward thinning and coarsening toward a crudely north-south-trending edge of the marine facies, and evidence of localized derivation from the south in some of the younger units. The thickness trends, like those of the southeast sector, imply fundamental tectonic control of relative rates of subsidence. In both sectors, the 25-m.y. or possibly longer duration of the sedimentary record of that tectonic control presents an opportunity for improving understanding of crustal conditions preceding the abrupt onset of opening of the Los Angeles Basin.

The patterns of areal extent, thickness, and empirical limits of the transgressive marine facies of Sespe and Vaqueros plus equivalent lower Miocene strata provide basic templates (figs. 3, 4) for reconstructing the paleogeology prior to the very different conditions that followed 17.4 Ma. These templates are used later in a preliminary reconstruction. Sources of clasts, directions of sediment transport, and the nature of the depositional environments augment thickness and facies patterns but are no substitute for them.

\section{Ages of Latest Oligocene and Early Mio- cene Marine Strata-Southeast and Northwest Sectors}

The age of our Vaqueros Formation facies, including partly correlative strata of the Lower Topanga (Dibblee and Ehrenspeck, 1990) and Trancas Formations, ranges from latest Oligocene (about $24 \mathrm{Ma}$ ) to latest early Miocene (about 17.5 Ma). This general age range is based upon a broad base of land mammal age ranges (Lucas and others, 1997; Whistler and Lander, 2003), marine mollusk age ranges (Yerkes and Campbell, 1979; Schoellhamer and others, 1981), benthic foraminiferal age ranges (Nagle and Parker, 1971; Yerkes and Campbell, 1979; Blake, 1983), magnetic polarity stratigraphy in several places (Prothero and others, 1996, figs. 8, 9, 11; Prothero and Donohoo, 2001, modified following suggestions of Whistler and Lander, 2003; Liddicoat, 2001; Ludtke and Prothero, 2003), several pertinent late Oligocene radiometric dates (Mason and Swisher, 1989; Nourse and others, 1998; McCulloh and others, 2001; Lander and others, 2003), and ${ }^{87} \mathrm{Sr} /{ }^{86} \mathrm{Sr}$ fossil carbonate dates (17.3 Ma) for the type area of the Topanga Formation (McCulloh and others, 2002, table 2).

Because a numeric age for the end of deposition of the youngest Sespe-Vaqueros Formation strata is important for our reconstruction and rate estimates, available pertinent biochronologic data were thoroughly investigated.

Correlations and age determinations that depend exclusively on fossil mollusks should be used with caution. Vertipecten bowersi Arnold occurs in a number of places in the Vaqueros Formation of both sectors. Although the upper limit of its stratigraphic range in California is considered by many to be within the provincial Saucesian benthic foraminiferal stage (about 19.5 Ma, according to Smith, 1991, figs. $1,12)$, the limiting data are weak, and it might range to the end of the Saucesian at about 17.5 Ma (Smith, 1991, fig. 10) or possibly even younger locally (Vedder, 1973). Similarly, the Turritella species T. ocoyana Conrad s.l. and T. inezana Conrad s.l. are considered by some (for example, Merriam, 1941; Campbell and Yerkes, 1979) to be guides to "Temblor" (<19.5 Ma) and "Vaqueros" (>19.5 Ma) provinicial molluscan stages, respectively. However, it has long been 
known that the two species co-occur in both sectors of our region (Loel and Corey, 1932, p. 264) and more widely in California (Vedder, 1973, fig. 9; Addicott, 1977, p. 158). Turritella ocoyana Conrad s.l. partly overlaps T. inezana Conrad s.1. but may range as young as 13.6 Ma. Turritella inezana may be restricted to strata older than $17.5 \mathrm{Ma}$.

The Vaqueros marine transgressive event ended abruptly in most if not all of the Los Angeles region between about 17.5 and 17.4 Ma. The timing is fixed by the age of the unconformable base of younger Topanga volcanics (Hoots, 1931) of the easternmost Santa Monica Mountains (McCulloh and others, 2002, fig. 4), by early Hemingfordian terrestrial mammalian assemblages from the uppermost undifferentiated Sespe-Vaqueros Formation of the northwestern Santa Ana Mountains (Lucas and others, 1997; Whistler and Lander, 2003, fig. 4), and by early late Hemingfordian land mammals from the Fernwood Member of the Topanga Canyon Formation (Yerkes and Campbell, 1979, fig. 3; Fritsche, 1993, fig. 4; Whistler and Lander, 2003, fig. 5). The timing is also compatible with ${ }^{87} \mathrm{Sr} /{ }^{86} \mathrm{Sr}$ ages of fossil shells from the Topanga Formation (Hoots, 1931) type section (McCulloh and others, 2002, table 2), with the $15.9 \pm 0.8 \mathrm{Ma} \mathrm{K}$-Ar age of the oldest reliably dated overlying Conejo Volcanics (Turner and Campbell, 1979, p. E21, table 1) after recalculation using current decay constants, and qualitatively with the conspicuous indications over much of the region of a substantial hiatus or erosional break separating Vaqueros Formation facies from overlying middle Miocene strata.

\section{Paleomagnetic Declinations and Transrotation- Northwest Sector}

Paleomagnetic declination data indicate that the western Transverse Ranges Province block underwent Neogene clockwise transrotation of as much as $100^{\circ}$ in some western parts beginning no later than $16 \mathrm{Ma}$ (Hornafius, 1985; Morris and others, 1986; Luyendyk and Hornafius, 1987; Liddicoat, 1990; Luyendyk, 1990) and continues to rotate today (Molnar and Gipson, 1994). The more-or-less fixed rotational hub is at the east end of the block, about $25 \mathrm{~km}$ east of this study's northwest sector. The block's southern edge coincides at least roughly with the Anacapa-Malibu Coast-Santa Monica-Hollywood-Raymond zone of linked faults, possibly with some complications east of the northwest projection of the Newport-Inglewood Fault Zone. The block presumably became mostly detached from its deep crustal foundation, was accreted to the northwestwardly moving Pacific Plate, and then constrained to rift and rotate away from the North American Plate attachment, driven by Pacific Plate divergent motion through basal shear (Nicholson and others, 1994; Dickinson, 1996; Atwater and Stock, 1998; Bohannon and Geist, 1998). The central and western parts of the northwest sector participated substantially in the transrotational migrations (Kamerling and Luyendyk, 1979;
Hornafius and others, 1986; Liddicoat, 1988, 2001). It is unclear that the eastern extension of the northwest sector, east of longitude $118^{\circ} 18^{\prime} \mathrm{W}$ and closer to the rotational hub, participated equally.

Paleomagnetic declination measurements and interpretations provide the essential quantitative and conceptual foundation for the transrotation of the western Transverse Ranges block. Published declination results from twelve sites are within (or closely on trend with) the northwest sector (table 1, fig. 5). Thoroughly documented declination results from stratiform rocks deposited, erupted, or intruded more than 10 m.y. ago are available for 10 northwest sector sites and one Anacapa Island site that is on trend $30 \mathrm{~km}$ (19 miles) farther west. Data from a twelfth site on the southwestern tip of Point Dume are more questionable because of sampling limitations due to access restrictions (Liddicoat, 1988).

The space-time patterns of paleomagnetic rotations in the northwest sector suggest two tendencies. First, the larger rotations $\left(80^{\circ}\right.$ to $\left.90^{\circ}\right)$ tend to occur in rock units 16 Ma and older. Second, rocks of approximately the same age in different parts of the sector record different rotations, suggesting a mosaic of structural blocks that have moved semi-independently. This second tendency is supported by data showing that Saugus Formation fluviatile strata (< 2.3 Ma) north of the Santa Susana Fault (outside our area) rotated clockwise about $30^{\circ}$ to $34^{\circ}$, whereas correlative units south of the fault (within our area) have not rotated (Levi and Yeats, 1993; 2001). Independently, McCulloh and others (2001, p. 19, 23) suggest that the northeastern continuation of the northwest sector probably records at least $20^{\circ}$ of clockwise rotation since 4 to $3 \mathrm{Ma}$.

\section{Preliminary Palinspastic Reconstruction}

\section{Introduction and Constraints}

Palinspastic reconstruction of the parts of the Los Angeles Basin region to the time when the youngest Vaqueros and Sespe strata were deposited requires back-rotation of our northwest sector to its 17.4 Ma position-but exactly to where? The stratified Neogene rocks and their deforming structures hold the answers, many of which have been gathered during the exploration for petroleum. Evidence is well summarized but scattered (Woodford and others, 1954; Yerkes and others, 1965; Nagle and Parker, 1971; Yeats, 1987; Wright, 1991; Blake, 1991; Rumelhart and Ingersoll, 1997; McCulloh and others, 2000; McCulloh and others, 2001; McCulloh and others, 2002). Although structural, tectonic, kinematic, chronostratigraphic, and paleodepositional-paleogeographic evidence does not constitute a sufficient basis for palinspastic reconstruction independently of the paleomagnetic data, it does impose time, sequence, and location constraints that are crucial for our preliminary 
Table 1.-Age, paleomagnetic declinations, basis, and published sources for well documented localities in the northwest sector of the greater Los Angeles basin region.

\begin{tabular}{|c|c|c|c|c|c|}
\hline $\begin{array}{l}\text { Map } \\
\text { Symbol } \\
\text { (on fig. 5) }\end{array}$ & $\begin{array}{l}\text { Declination } \\
\text { (degrees) }\end{array}$ & $\begin{array}{l}\text { Age } \\
\text { (Ma) }\end{array}$ & Unit(s) & $\begin{array}{c}\text { Number of } \\
\text { measurements }\end{array}$ & Source \\
\hline 1 & $80.8-76.8$ & $16 \pm ?$ & four dikes & 30 & Kammerling and Luyendyk, 1979. \\
\hline 2 & 79.0 & $16 \pm ?$ & four dikes & 20 & Kammerling and Luyendyk, 1979. \\
\hline 3 & 59.2 & $>10 \&<15$ & one dike & 22 & Kammerling and Luyendyk, 1979. \\
\hline & $\begin{array}{l}59.2 \\
32.5 \\
70.8\end{array}$ & $\begin{array}{c}10.1 \pm 2 \\
<10.1 \pm 2 \\
\text { ca. } 10 ?\end{array}$ & $\begin{array}{l}\text { one dike } \\
\text { two dikes } \\
\text { three dikes }\end{array}$ & $\begin{array}{c}8 \\
13 \\
23\end{array}$ & \\
\hline 4 & & ca. IU! & three dikes & & Kammerling and Luyendyk, 1979. \\
\hline 5 & 64.0 & $16.28 \pm 0.18$ & ten flows & 49 & $\begin{array}{l}\text { Kammerling and Luyendyk, 1979; } \\
\text { Luyendyk and others, 1998, table } 1 .\end{array}$ \\
\hline 6 & 65.7 & $11.3-13.3$ & $\begin{array}{l}\text { three dolomite } \\
\text { beds }\end{array}$ & 16 & $\begin{array}{l}\text { Hornafius and others, 1986, fig. } 3 \text {, } \\
\text { table A. }\end{array}$ \\
\hline 7 & 60.7 & $11.3-13.3$ & $\begin{array}{l}\text { one dolomite } \\
\text { bed }\end{array}$ & 4 & $\begin{array}{l}\text { Hornafius and others, 1986, fig. } 3 \text {, } \\
\text { table A. }\end{array}$ \\
\hline 8 & 35.9 & $11.5 \pm 1.2$ & $\begin{array}{l}\text { two dolomite } \\
\text { beds }\end{array}$ & 11 & $\begin{array}{l}\text { Hornafius and others, 1986, fig. } 3 \text {, } \\
\text { table A. }\end{array}$ \\
\hline 9 & 77.5 & $14.6 \pm 1$ & $\begin{array}{l}\text { Zuma Volcanics } \\
\text { of Point Dume }\end{array}$ & unk & $\begin{array}{l}\text { Liddicoat, 1988; } \\
\text { Berry and others, } 1976 .\end{array}$ \\
\hline 10 & 94 & ca. 28 & $\begin{array}{l}\text { Sespe Fm. at } \\
\text { South Mountain }\end{array}$ & unk & Liddicoat, 2001. \\
\hline 11 & 64 & $>38$ & $\begin{array}{l}\text { Sespe Fm. of } \\
\text { Simi Valley }\end{array}$ & unk & Liddic oat, 2001. \\
\hline 12 & $80 \pm 9$ & $>80$ & $\begin{array}{l}\text { "Tuna Canyon" } \\
\text { Fm; eastern end } \\
\text { of central Santa } \\
\text { Monica Mtns. } \\
\text { (two sites) }\end{array}$ & 12 & Morris and others, 1986. \\
\hline
\end{tabular}

reconstruction. Therefore selected diagnostic post-20 Ma events are summarized in figure 6.

Submarine basaltic volcanism began the Neogene evolutionary phase in the easternmost Santa Monica Mountains at 17.4 Ma (McCulloh and others, 2002). Volcanism intensified in early middle Miocene time, became more andesitic and partly subaerial, and spread to the western and northwestern and to the eastern and southeastern parts of the region (Shelton, 1954; Vedder and others, 1957; Eaton, 1958; Yerkes and Campbell, 1979; Dibblee, 1982, p. 102). The latest phase of volcanism apparently occurred in the southeast sector, concluding perhaps at 11 to $10 \mathrm{Ma}$
(Yerkes, 1957; Yerkes, 1972; Luyendyuk and others, 1998; McCulloh and others, 2000; Bjorklund and others, 2002). Volcanism was temporally and spatially associated with crustal extension and widespread faulting "on northwestand north-trending faults" in the southeastern Los Angeles Basin (Wright and others, 1973; Wright, 1991, p. 92), and along northeast- to nearly east-trending faults (present coordinates) in the northwest sector (Yeats, 1983, fig. 3).

Rapid regional subsidence in the Los Angeles Basin followed volcanism and led to deposition of very thick deepsea fan and plain deposits (Redin, 1991), mainly between 13 and 5 Ma. Dextral slip on northwest trends began during 
Pliocene time in the Los Angeles Basin. A regime of northsouth transpression marked by reverse faulting became pronounced in Pliocene-Pleistocene time and is continuing (Hauksson and Jones, 1989; Hauksson and others, 1995; Wilde and Stock, 1997; Oskin and others, 2000; Bawden and others, 2001).

A preliminary palinspastic reconstruction of the Los Angeles Basin region (fig. 7) emerges when the Neogene events (fig. 6) are combined with paleomagnetic declinations from sites in the northwest sector (fig. 5), and both are coupled with thickness and facies templates of Sespe and Vaqueros Formations (figs. 3, 4).

\section{Back-Slip of Fault Separations}

Creation of a palinspastic reconstruction required undoing a variety of fault movements. First, a crude restoration was made of the north-south and northeast-southwest shortening within the Los Angeles Basin and adjacent areas (Yerkes, 1972; Davis and others, 1989; Wright, 1991; Pratt and others, 1998; Shaw and Shearer, 1999; Oskin and others, 2000; Tsutsumi and others, 2001).
Back-slip to correct for right oblique reverse and strike slip on the Whittier Fault Zone and the continuation on the Elsinore Fault was next imposed (McCulloh and others, 2000). Contemporaneous back-slip was also applied to compensate for left oblique strike and reverse slip on the Raymond-Hollywood-Santa Monica Fault Zone (Jones and others, 1990; Pratt and others, 1998; McCulloh and others, 2001). Earlier left slip on the Benedict Canyon Fault (Hoots, 1931; Durrell, 1954) was assumed to join later left oblique reverse slip of the Santa Monica Fault Zone west of the concealed junction of these faults. We combine the two slips west of the junction and call for right back-slip of $16 \mathrm{~km}$ (10 miles), plus an unmeasured amount of composite dip back-slip on the Malibu Coast Fault. Fully equivalent restorations for the Malibu Coast and Anacapa Faults were not feasible, even though the linkage and kinship of these faults to the Santa Monica-Hollywood-Raymond zone of reverse, oblique, and left-slip active faults is widely recognized (Pratt and others, 1998, p. 480).

Post-late Pliocene right slip on the Newport-Inglewood Fault Zone is at least $1.2 \mathrm{~km}$ at some places (Wright, 1991, p. 66). Older strike slip, possibly before $5 \mathrm{Ma}$, may be substantial (Hazenbush and Allen, 1958). Middle Miocene dip slip on an originally northeast-dipping normal "Wardlow" fault branch

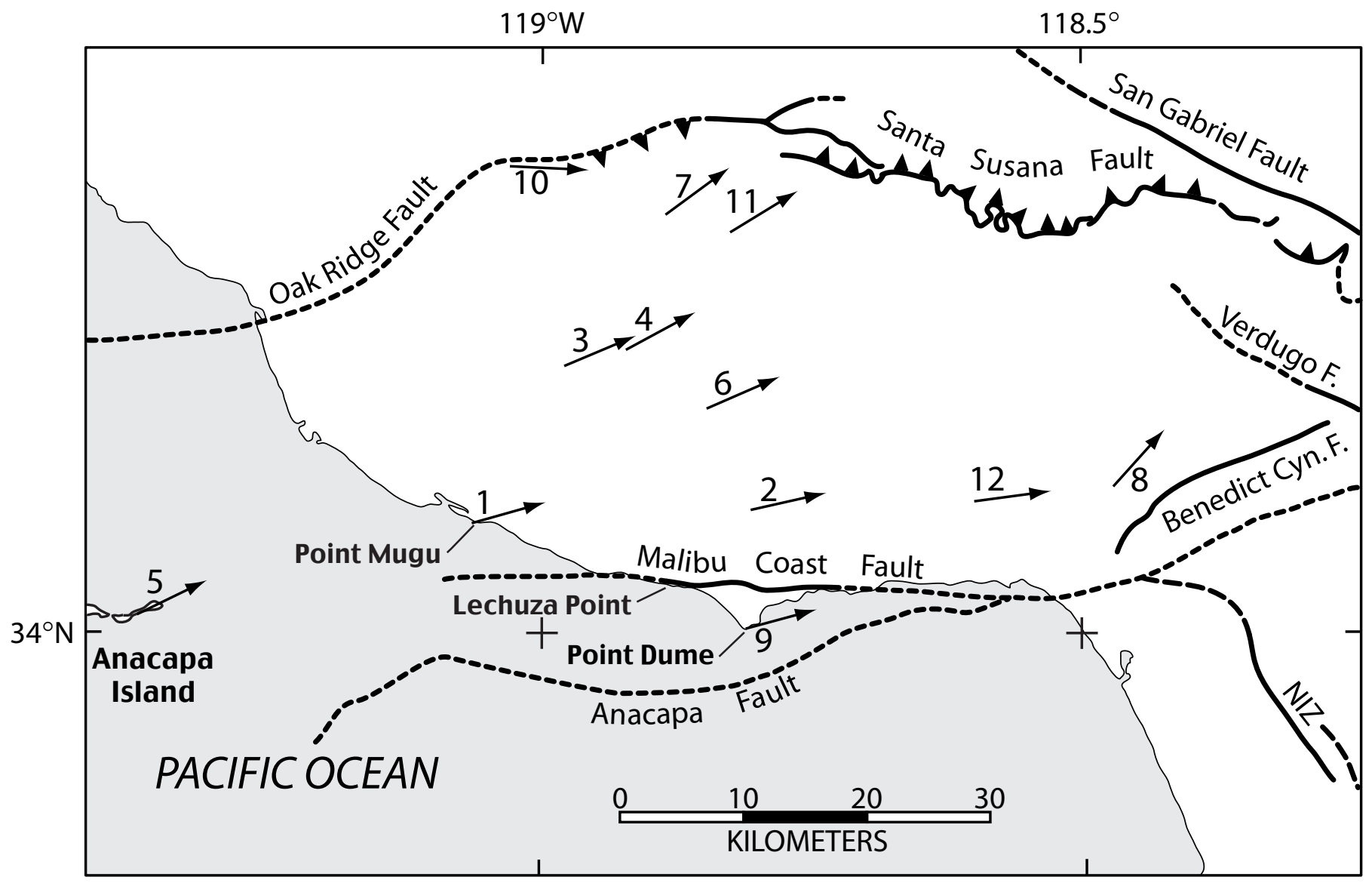

Figure 5.-Map of paleomagnetic declinations for rocks erupted or intruded before $10 \mathrm{Ma}$ in the northwest sector compiled from published sources (numbered as in table 1), with major faults and selected geographic features. NIZ-Newport-Inglewood Fault Zone. 


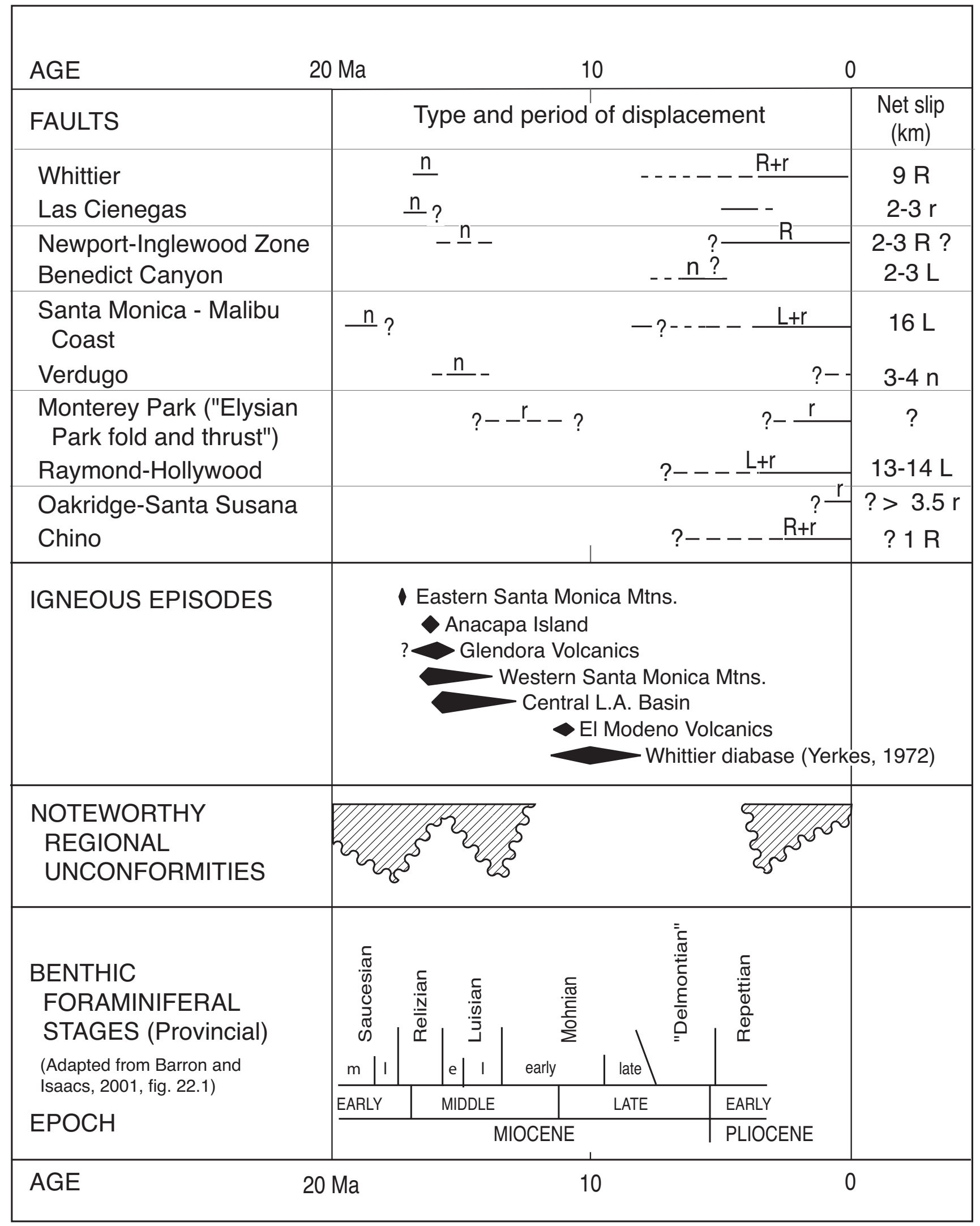

Figure 6.-Major fault separation estimates, noteworthy regionally developed unconformities (or depositional interruptions), and important igneous episodes of the greater Los Angeles region summarized in simplified form with a time framework. " $R$ " and " $L$ " indicate right-lateral and left-lateral strike slip, respectively; " $n$ " and " $r$ " indicate normal and reverse slip, respectively. 


\section{EXPLANATION}

SESPE-VAQUEROS UNDIFFERENTIATED (includes Trancas Formation)

Outcrops

Subsurface nonmarine only

Subsurface partly marine

Line of equal thickness in feet

(dashed and dotted where less certain)

PRE-CRETACEOUS ROCKS

Outcrops of Peninsular Ranges Province basement lithologies

Outcrops of Santa Monica Slate and intrusive granodiorite

Area known or reasonably inferred to be floored by Catalina Schist

Area known or reasonably inferred to be floored by Peninsular Ranges Province basement lithologies

Area where this reconstruction infers that the Santa Monica Mountains terrane overrides Catalina Schis

CONTACT RELATIONS

Reconstructed basin margin

Erosional edge

Edge of marine facies

Gap generated by palinspastic reconstruction, suggesting

expression of present-day overthrusting

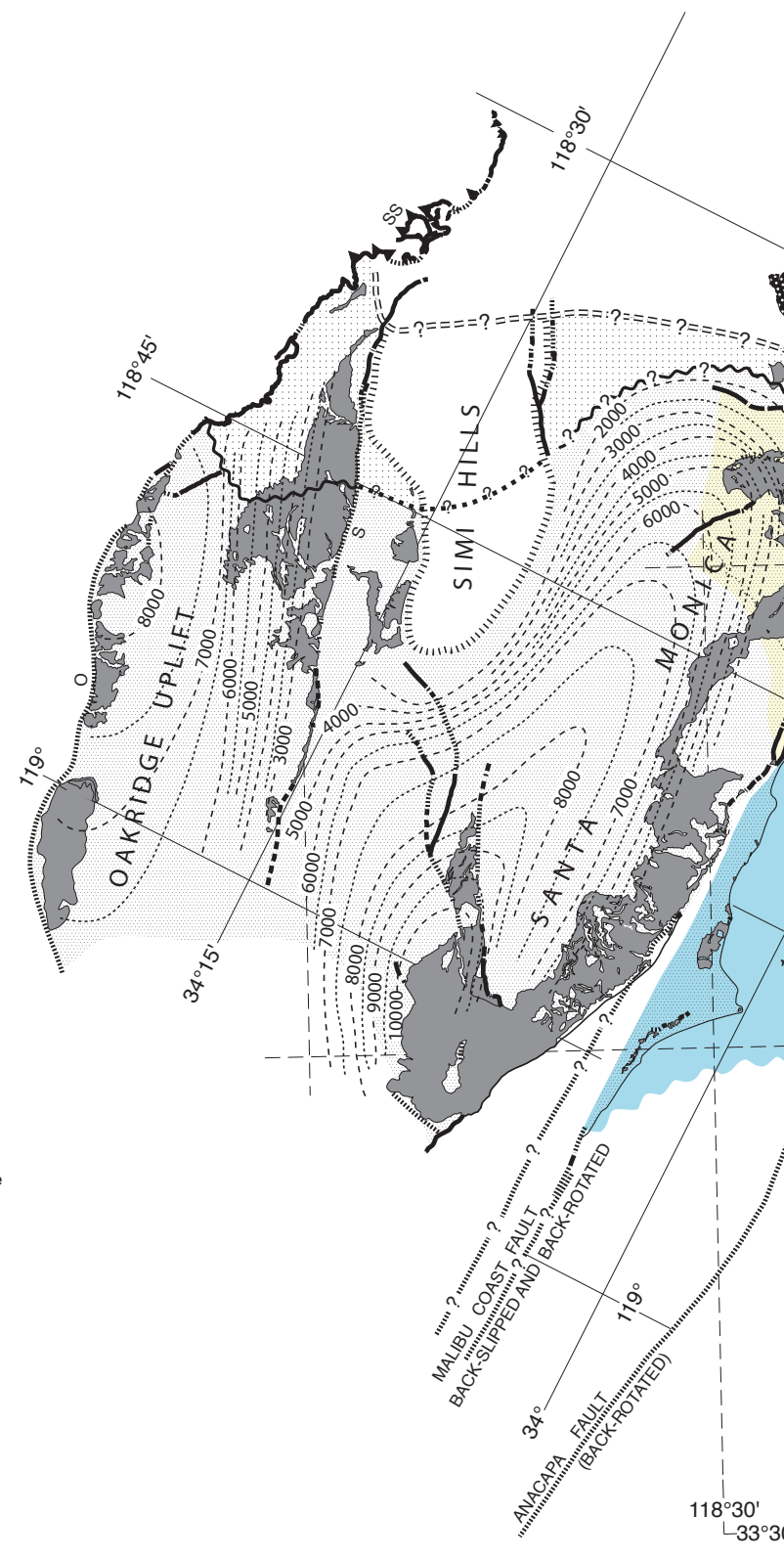

Important faults (long dash where uncertain, shor

dash where inferred, and queried where doubtful)

$-\phi 60$

Prospect well that provides critical insight (see appendix 3 )

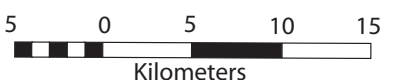

Figure 7.-Preliminary palinspastic reconstruction of the greater Los Angeles Basin region based on the paleodepositional templates for the northwest and southeast sectors (figs. 3, 4), paleomagnetic declinations 


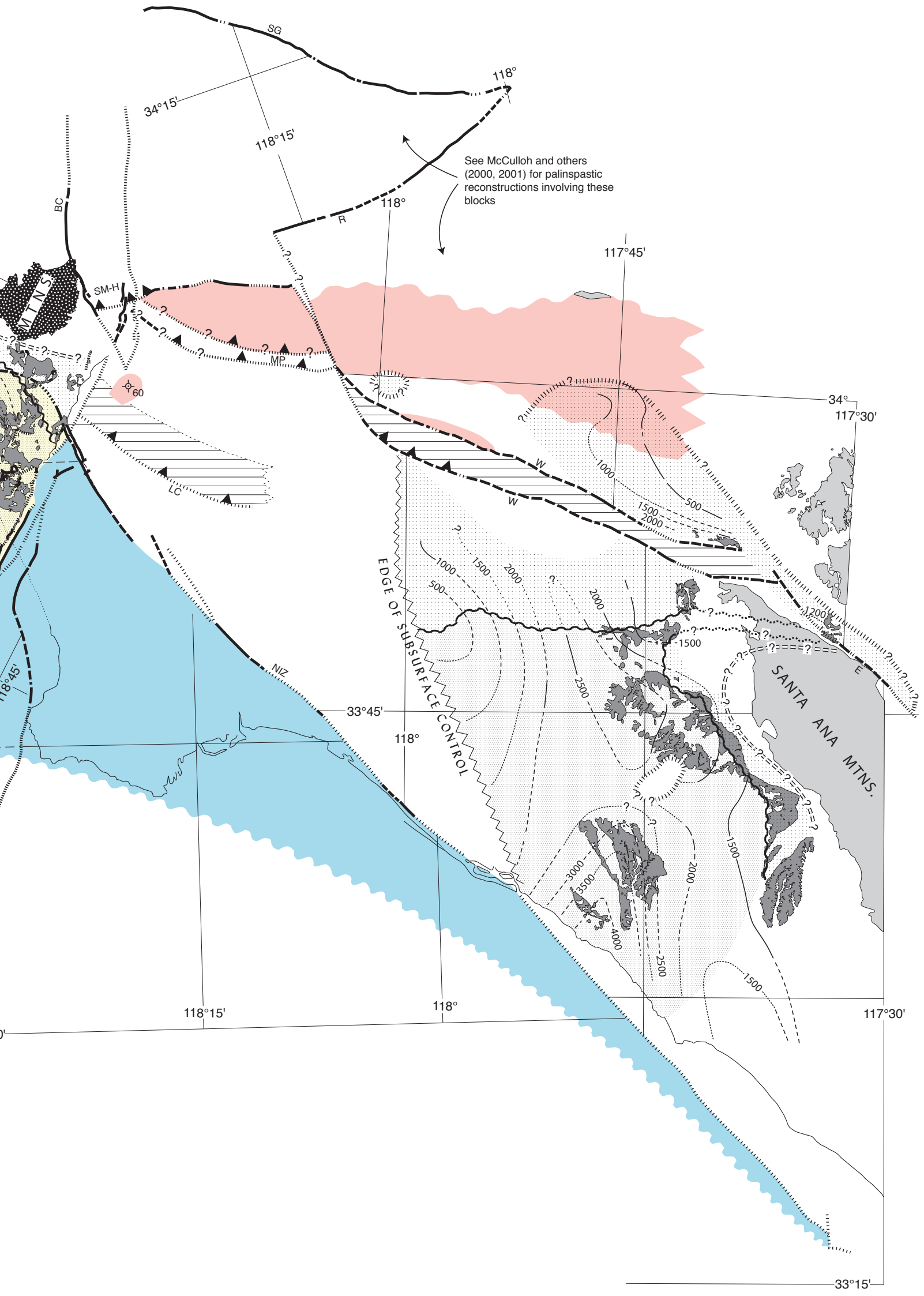

(fig. 5, table 1), and the deformations summarized on figure 6. MP—Monterey Park Fault; see figure 1 for other fault-name abbreviations. 
of the Newport-Inglewood Fault Zone may exceed $0.5 \mathrm{~km}$ (Harris, 1958). Our preliminary reconstruction for the Newport-Inglewood Fault Zone removes 2 to $3 \mathrm{~km}$ of right slip.

The Las Cienegas Fault, which probably originated as a southwest-dipping normal fault in middle Miocene time, was reactivated as a northeast- to north-dipping reverse fault beginning roughly at $5 \mathrm{Ma}$ (Schneider and others, 1996). This fault, known mainly through petroleum drill holes but mapped geophysically to the east of the Las Cienegas oil field as the "Huntington Park fault" (McMurdie and others, 1973), shows a minimum reverse separation of about 2 to 3 $\mathrm{km}$ and contributes to the northeast-southwest transpressive shortening previously mentioned. The amount of normal dip-slip separation that may have occurred during middle Miocene is highly uncertain and not addressed here. Evidence of middle Miocene extension along the Whittier Fault trend is indirect and summarized elsewhere (McCulloh and others, 2000), as is more concrete evidence for early normal faulting on the Verdugo Fault (McCulloh and others, 2001). Back-slip to account for these weakly documented early extensions also has not been included in the preliminary reconstruction and probably has minimal impact on the restoration.

\section{Restoration of Rotation}

Incorporation of rotational evidence into our reconstruction is a challenge. Although an assumed constant clockwise rotation rate of " 5.79 deg./m.y." has been suggested for the western Santa Ynez Range northwest of our region (Luyendyk, 1991, fig. 7), there is no reason to suppose that the entire northwest sector fits that model. In fact, a very different approach (Dickinson, 1996, table 2) leads to the appealing result that the region is segmented with different segments having undergone different amounts of rotation (but at the constant rate of " $5.8^{\circ} \pm 0.1^{\circ} / \mathrm{m}$.y.") that ceased at different times. An even more complicated history is conceivable, in which a mosaic of fault blocks in the northwest sector rotated semi-independently instead of the " $56^{\circ}$ " or " $77^{\circ}$ " averages for the pertinent "domains" of Dickinson (1996, fig. 9).

Recognizing that published data allow for a range of possible interpretations, the following three assumptions are adopted for our reconstruction: (1) The entire body of northwest sector rocks older than $17.4 \mathrm{Ma}$ rotated $80^{\circ}$ clockwise, the maximum supported by most data, at a constant rate from start to the present. All Trancas Formation and Zuma Volcanics between the Anacapa and Malibu Coast Faults also rotated $80^{\circ}$. (2) The area of all Sespe Formation or older Cenozoic outcrops east to about Cahuenga Pass (longitude $118^{\circ} 18^{\prime} \mathrm{W}$ ) near the east end of the Santa Monica Mountains rotated clockwise only $40^{\circ}$ since about $13 \mathrm{Ma}$. (3) The area at the easternmost end of the range may have rotated about $20^{\circ}$ clockwise, but only since about $4 \mathrm{Ma}$.

While other assumptions may prove correct, those outlined above seem to best fit available data. The preliminary reconstruction shown in figure 7 embodies the above rotation assumptions, together with the restorations of fault offsets previously discussed and summarized (fig. 6).

\section{Discussion}

Most noteworthy in our preliminary reconstruction is the degree to which the templates of the Sespe-Vaqueros Formations fail to join, despite strong but possibly relatively superficial similarities. Very substantial gaps remain between the two partly erosional Sespe-Vaqueros basin margins and the separated (or separate?) marine-nonmarine facies limits, despite the substantial angular and translational restoration. Equally impressive, although strong similarities are evident in the isopach patterns for the two sectors, attempts to unify them spatially fail. Foremost in the failure is the fact that a projection of the combined Sespe-Vaqueros thickness in the northwest sector is 600-900 m (2,000-3,000 ft) along the Malibu Coast Fault. Presumably this projected thickness must approach zero between the Anacapa and Malibu Coast Faults, where blocks of San Onofre Breccia (Woodford and Bailey, 1928) and finer Catalina Schist detritus were eroded during deposition of the Trancas Formation and parts of the "Lower Topanga" or "Topanga Canyon Formation" (Campbell and others, 1996). The Sespe-Vaqueros Formations of the southeast sector also thin toward the western edge of drill hole control to a minimum of less than $150 \mathrm{~m}(500 \mathrm{ft})$. Secondarily, after backrotation, the nearly east-west isopach trends of the northwest sector fail to parallel the similar (north-south) isopach trend of the southeast sector. An unobserved additional back-rotation of the northwestern sector of $20^{\circ}-25^{\circ}$, or commensurate rotations of both sectors to total about $100^{\circ}$, is needed to fully align isopach trends. Because we view these thickness trends as products of long-term tectonic control of alternating belts of subsidence and relative uplift before $17.4 \mathrm{Ma}$, their remaining divergence after back-rotation suggests that information may be missing and that our reconstruction therefore is deficient.

The absence of compellingly trustworthy magnetic declination data in the southeast sector also adds uncertainty to our restoration. Some results suggest counterclockwise rotation of $26^{\circ}$ to $36^{\circ}$ for Cretaceous and latest Paleocene strata of the northern Santa Ana Mountains (Morris and others, 1986, table 1). However, other results suggest " $69^{\circ}$ $\pm 15^{\circ}$ " clockwise rotation for latest Paleocene in the same area (Prothero and Lopez, 2001) and no rotation for Sespe Formation in the same general area (Prothero and Donohoo, 2001). More and better data are needed.

The Newport-Inglewood Fault Zone is the northeastern limit of all known Catalina Schist in the region. Reconstructions calling for a Catalina Schist floor beneath the Los Angeles Basin northeast of the Newport-Inglewood fault zone are hypothetical (Crouch and Suppe, 1993; Bohannon and Geist, 1998) and model-dependent. Similarly, the present-day Malibu Coast Fault is also believed to be the northern limit of 
Catalina Schist (Yerkes and Campbell, 1979). The back-rotation of $80^{\circ}$ used in our trial reconstruction still leaves an angle of about $60^{\circ}$ between the restored outcrop course of the Santa Monica-Malibu Coast Fault and the present overall course of the Newport-Inglewood Fault Zone (fig. 7), assuming that no other horizontally substantial translations or other cryptic factors intervened. Evidence for greater back-rotation to explain this apparent misfit is lacking.

Our preliminary reconstruction is similar to one proposed for 16 Ma by Hornafius and others (1986, fig. 9), even though respective underlying assumptions about fault offsets differ substantially. It is also similar to palinspastic reconstructions to 14 to $13 \mathrm{Ma}$ of Luyendyk (1990, fig. 5a; 1991, fig. 5) and, in some ways, to a more complex and comprehensive reconstruction to $19 \mathrm{Ma}$ by Sorlien and others (1999, fig. 13B). Critical differences from our reconstruction are evident in the restoration described by Crouch and Suppe (1993, fig. 4 and p. 1421), not the least of which are " $110^{\circ}$ " of clockwise rotation of the northwest block and "30 km" of left slip on the Malibu Coast-Raymond Fault Zone. However, the " $110^{\circ}$ " of rotation of Crouch and Suppe (1993), while not based on pertinent observations and greater than our allowed $80^{\circ}$, would lessen spatial discrepancies between the facies and thickness trends of our restored templates of the Sespe-Vaqueros Formations. The discordance between our restored trend of the Santa Monica-Malibu Coast Fault Zone and the trend of the Newport-Inglewood Fault Zone would also be reduced. Lastly, separate but possibly also critical differences are seen between our reconstruction and that of Bohannon and Geist (1998, fig. 14) which elaborates a central hypothesis of the Crouch and Suppe (1993) model.

\section{Uncertainties and Future Challenges}

Our work highlights several substantial uncertainties that stand in the way of reliably restoring the Los Angeles Basin region to its prerift configuration. We believe the following complexities and uncertainties impose possibly significant implications for any palinspastic reconstruction, including ours.

\section{Limits of Paleomagnetic Declination Data}

Presently available declination data for the central and western Santa Monica Mountains are immensely valuable but are largely restricted to volcanic rocks that probably are not older than 15.9 \pm 0.8 Ma (Turner and Campbell, 1979, table 1 and p. E21, with recalculation using current decay constants). Do redbeds of the substantially older underlying Sespe Formation in the same area show the same or different rotations?

No paleomagnetic declination data are published for rocks of the easternmost Santa Monica Mountains. Because the Topanga volcanics (Hoots, 1931) of that area have been shown to be 17.4 Ma (McCulloh and others, 2002), substantially older than the base of the Conejo Volcanics farther west, knowledge of postvolcanism rotation there would be exceptionally useful.

Deformed nonmarine Saugus Formation strata that are 2.3 Ma and younger in the northernmost part of the northwest sector have undergone no rotation (Levi and Yeats, 1993). Knowledge of the full areal extent of the unrotated rock mass and how far back in time that condition extends would help reconstruction efforts. Outcrops that are old enough and lithologically suitable for paleomagnetic determinations are limited. The Pacoima Hills (Oakeshott, 1958; Dibblee, 1991) in the northern San Fernando Valley, where nonmarine redbeds of Hemingfordian age Topanga Formation are overlain by middle Miocene Topanga volcanics, might offer possibilities.

\section{Early Extensional Tectonism Along the Malibu Coast-Santa Monica Fault Zone}

The Malibu Coast Fault Zone dips $30^{\circ}$ to $70^{\circ}$ to the north and records Pliocene and younger north-over-south thrusting where it is best known (Campbell and others, 1996; Seeber and Sorlien, 2000). Just west of $118^{\circ} 30^{\prime} \mathrm{W}$ longitude at the coastline, the linked Santa Monica Fault Zone consists of two north-dipping breaks, a younger northern reverse fault, and an older southern reverse fault that appears to have been active only between $5 \mathrm{Ma}$ and about $1.5 \mathrm{Ma}$ (Pratt and others, 1998). Another $10 \mathrm{~km}$ eastward, the Santa Monica Fault and its splays dip north and show Pliocene to Quaternary reverse slip, but probable "early to late Miocene normal" slip (Tsutsumi and others, 2001). Added to this complex record is evidence for 13 to $14 \mathrm{~km}$ of left strike-slip separation for the Raymond-Hollywood Fault segment probably since $5 \mathrm{Ma}$ (McCulloh and others, 2001, p. 18) and another $2.4 \mathrm{~km}$ of left slip from the Benedict Canyon Fault (that joins west of longitude $118^{\circ} 30^{\prime} \mathrm{W}$ ), thus totaling about $16 \mathrm{~km}$ of left slip feeding onto the Malibu Coast Fault. This contrasts with fairly compelling evidence of only about $12 \mathrm{~km}$ of left separation west of Point Dume, based on glaucophane-bearing breccia at Lechuza Point south of the fault and glaucophane-bearing sandstone just east of the mouth of Sycamore Canyon north of the westward extension of the fault. Possibly some left slip is on the Anacapa Fault. Alternatively, interactions between northwest-striking right-slip faults and west-striking left-slip zones might explain the $4 \mathrm{~km}$ difference.

In the central Santa Monica Mountains, the thick section of Cretaceous marine, Paleocene nonmarine and marine, and Eocene marine strata (Colburn, 1973; Carey and Colburn, 1978; Yerkes and Campbell, 1979; Colburn and others, 1981; Colburn, 1996; Campbell and others, 1996), plus thousands of feet of nonmarine Sespe Formation strata, is present only north of the Malibu Coast Fault. South of the fault, Trancas Formation beds might be as 
young as slightly less than 19 Ma and most likely rest on Catalina Schist. Back slip of the 12 or $16 \mathrm{~km}$ of left-lateral strike movement on the Malibu Coast Fault does not alter these relationships. We judge from these and related facts that early movements on the Malibu Coast Fault probably occurred between 19 and 17.4 Ma and were extensional, with the north block (present coordinates) downthrown by more than 2 to $3 \mathrm{~km}$. Presumably the Zuma and Tuna Canyon detachment faults (Campbell and others, 1996) are lesser but analogous structures within this extremely thick sedimentary section. Whether the early extensional slip included the Hollywood Fault Zone to the east is difficult to determine. Such slip is possible to likely because the oldest volcanic rocks in the region (17.4 Ma) probably occur only north of the fault zone (McCulloh and others, 2002), or west-northwest of it after our restoration.

\section{Central Trough of the Los Angeles Basin}

The metasedimentary, metavolcanic, and metaplutonic rocks reached by drilling in the northwestern part of the Los Angeles Basin are important constraints on the mechanisms of basin opening and therefore on palinspastic reconstructions. Most of these rocks are extensively described (Schoellhamer and Woodford, 1951; Yerkes and others, 1965, fig. 5 and p. A21-A24; Yeats, 1973; Sorenson, 1985; McCulloh and others, 2001, fig. 2, table 4). Their distribution limits the area of poorly known and unknown basin floor to the northwestern region of the central trough between the Las Cienegas Fault on the north and the Newport-Inglewood Fault Zone to the southwest. The exact nature of basement rocks and the deep overlying sedimentary units in this area of the Los Angeles Basin is poorly documented. Multiple modeldependent hypotheses have been advanced, either directly through a range of assumptions or interpretations, or indirectly through unstated inferences (McCulloh, 1960; Yerkes and others, 1965, figs. 5-7 and p. A24-A28; Crowell, 1974, especially p. 201-202; Crowell, 1987; Mayer, 1991; Redin, 1991, fig. 4; Crouch and Suppe, 1993, p. 1419-1421 and fig. 4; Langenheim and Jachens, 1996; Shaw and Suppe, 1996; Bohannon and Geist, 1998, fig. 14; Kaban and Mooney, 2001, fig. 11; Bjorklund and others, 2002).

The presence of at least partly submarine middle Miocene volcanic rocks around the perimeter of the central trough encourages us to believe that trough evolution involved localized volcanic upwelling in the early subsidence stages (Crowell, 1987, p. 225; McCulloh and others, 2002). This suggests localized extension in a restricted zone of rifting, possibly along breaks striking about $\mathrm{N} 10^{\circ} \mathrm{W}$, like those compiled from volcanic dike outcrops in the San Joaquin Hills by Yeats (1974, fig. 1). In the absence of more concrete and unequivocal evidence, these uncertainties will continue to permit a range of model-dependent constructs. However, the filled young central trough of the Los Angeles Basin south of the Las Cienegas Fault and west of the southeast sector most likely is a passive by-product of some form of extensional transrotation. Is it one of the "triangular or transrotational basins [that] open at the join between rotating and nonrotating crust in the deforming zone" (Luyendyk, 1991, p. 1533)?

\section{Junction of the Inglewood and Santa Monica Fault Zones}

Multiple subsurface complexities along the entire onshore trace of the Newport-Inglewood Fault Zone are not nearly as complicated as those near and at its northwest junction with the Santa Monica Fault Zone (Yeats, 1973, fig. 2; Lang and Dressen, 1975; Jacobson and Lindblom, 1987; Wright, 1991, fig. 14; Schneider and others, 1996, fig. 8; Tsutsumi and others, 2001, fig. 2). A key uncertainty is whether the late right slip of $1.2 \mathrm{~km}$ on the NewportInglewood Fault Zone at Inglewood oil field (Wright, 1991, p. 66) breaks and offsets splays of the Santa Monica Fault along what is called the "West Beverly Hills lineament" (Tsutsumi and others, 2001) or finds its way instead onto the northeast-dipping Rancho fault breaks (of Lang and Dreesen, 1975, fig. 3) along the southwest margin of and beneath the Cheviot Hills oil field (Wright, 1991, fig. 14). Although other uncertainties in this northwestern corner of the Los Angeles Basin importantly influence our reconstruction, probably none is more consequential than these. The cross section through the "Inglewood fault?" north of the Cheviot Hills oil field of Tsutsumi and others (2001, fig. 4, section G-G') suggests that post-7.5 Ma right slip probably was absorbed by the "Rancho fault" (as suggested by Lang and Dreesen, 1975). If so, that right slip probably effectively cancels some left slip on the Santa Monica Fault Zone west of the Sawtelle oil field, where the Rancho and Santa Monica Fault Zones presumably merge (Wright, 1991, fig. 14). Separately, possible pre-7.5 Ma right slip on a throughgoing extension of the Inglewood Fault along the "West Beverly Hills lineament" could have evaded detection and might explain the presence (slightly farther east) of the singular subsurface occurrence of "Sespe" (Yerkes and others, 1965, fig. 5, p. A23) or "Paleocene" redbeds (Yeats, 1973, p. 135; Tsutsumi and others, 2001, fig. 4E) overlain by volcanics and resting on "granite" in the Morgan Brown "Oil District U-6" No. 1 (appendix 1).

\section{Conclusion}

This study was motivated by the need for a synoptic picture of the regional geology of coastal southern California prior to transrotation of the western Transverse Ranges and the concomitant opening of the Neogene Los Angeles Basin. Outcrop and exploration drill hole information were used to compile a regional map of the areal extent, thickness variations, and lithofacies of Eocene-lower Miocene Sespe and Vaqueros Formations plus their equivalents. Two separate 
sectors of the region emerged, each having distinctive thickness patterns and both exclusively nonmarine and partially marine facies depositional patterns. Taken together, the interfingering clastic formations extend over more than 2,000 $\mathrm{km}^{2}$ in area and occupy more than $3,900 \mathrm{~km}^{3}$ in volume.

Exploring how these two now-separate sectors may have been related before transrotation required that we assemble and use trustworthy published paleomagnetic declination data to retro-deform the region. This palinspastic reconstruction, a primary product of this study, also required coordinated use of information about movements on major fault zones.

The preliminary palinspastic reconstruction of figure 7 will surely be modified and replaced. However, it is a step beyond prior reconstructions covering the same region and brings critical unanswered questions into focus. Understanding the time of emergence of Catalina Schist along the coast south of the Malibu Coast Fault is crucial. More precise dating of San Onofre Breccia along the Malibu Coast would provide new indirect limits on the mechanism responsible for exposing Catalina Schist to subaerial erosion prior to and accompanying the $17.4 \mathrm{Ma}$ onset of rifting that initiated opening of the Los Angeles Basin. Improved understanding of the interactions between the Malibu Coast-Santa Monica Fault and the Newport-Inglewood Fault Zone would provide insights about the evolution of the central trough as well as the transrotational opening of the entire Los Angeles Basin. New or additional internally consistent paleomagnetic declination data from Cretaceous or Paleogene and younger strata in both the northwest and southeast sectors are needed to improve the preliminary model presented here. Lastly, the Sespe and Vaqueros templates themselves (figs. 3, 4) should help to refine and test future palinspastic reconstructions of the Los Angeles Basin region.

\section{Acknowledgments}

Our work was possible because of the groundbreaking paleomagnetic declination results of M. J. Kamerling, B. P. Luyendyk, J. S. Hornafius, and J. C. Liddicoat. Geologic maps of the Santa Monica Mountains west of longitude $118^{\circ}$ 33' 50" W by R. H. Campbell, R. F. Yerkes, and their associates provided an essential base for our work. Key drill hole samples and data were provided by the California Well Sample Repository, Aera Energy LLC (C. James), Chevron U.S.A. Inc. (J. Urbach), Nuevo Energy (N. Livingston), Unocal (R. Moag), and Mobil Oil Corp. The University of Texas at Dallas and R. E. Denison made valuable contributions. We thank personnel of the National Park Service for access to critical Santa Monica Mountains sites. Interactions with the following colleagues were especially helpful: S. P. Buck, R. H. Campbell, I. P. Colburn, S. W. Conkling, R. J. Enrico, J. S. Hornafius, J. W. Hillhouse, E. B. Lander, D. R. Prothero, J. E. Schoellhamer, J. G. Vedder, and R. F. Yerkes. We are especially grateful to R. H. Campbell, J. W. Hillhouse, and J. G. Vedder for careful and helpful reviews. C. L. Powell II and Zenon Valin kindly prepared the figures.

\section{References}

Addicott, W. O., 1977, Neogene chronostratigraphy of nearshore marine basins of the eastern Pacific, in Saito, Tsunemasa, and Ujiié, Hiroshi, eds., Proceedings of the First International Congress on Pacific Neogene Stratigraphy, Tokyo 1976: International Union of Geological Sciences, Commission on Stratigraphy, Regional Committee on Pacific Neogene Stratigraphy, p. 151-175.

Arnold, R., 1907, New and characteristic species of fossil mollusks from the oil-bearing Tertiary formations of southern California: U. S. National Museum Proceedings, v. 32, p. 525-546.

Atwater, T., and Stock, J., 1998, Pacific-North America platetectonics of the Neogene southwestern United States; an update: International Geology Review, v. 40, p. 375402.

Bailey, T. L., 1947, Origin and migration of oil into Sespe redbeds, California: American Association of Petroleum Geologists, v. 31, p. 1913-1935.

Barron, J. A., and Isaacs, C. M., 2001, Updated chronostratigraphic framework for the California Miocene, in Isaacs, C. M., and Rullkötter, Jürgen, eds., The Monterey Formation from rocks to molecules: New York, Columbia University Press, p. 393-395.

Bawden, G. W., Thatcher, W., Stein, R. S., Hudnut, K. W., and Peltzer, G., 2001, Tectonic contraction across Los Angeles after removal of groundwater pumping effects: Nature, v. 412, p. 812-815.

Belyea, R. R., and Minch, J. A., 1989, Stratigraphy and depositional environments of the Sespe Formation, northern Santa Ana Mountains, California, in Colburn, I. P., Abbott, P. A., and Minch, J., eds., Conglomerates in basin analysis; A symposium dedicated to A. O. Woodford: Society of Economic Paleontologists and Mineralogists, Pacific Section, Book 62, p. 281-300.

Berry, A. L., Dalrymple, G. B., Lanphere, M. A., and Von Essen, J. C., compilers and editors, 1976, Summary of miscellaneous potassium-argon age measurements, U. S. Geological Survey, Menlo Park, California, for the years 1972-1974: U. S. Geological Survey Circular 727, 13 p.

Bjorklund, Tom, Burke, Kevin, Zhou, Hua-Wei, and Yeats, R. S., 2002, Miocene rifting in the Los Angeles basin; evidence from the Puente Hills half-graben, volcanic rocks, and Pwave tomography: Geology, v. 30, p. 451-454.

Blake, G. H., 1983, Benthic foraminiferal paleoecology and biostratigraphy of the Vaqueros Formation, Big Mountain area, Ventura County, California, in Squires, R. L., and Filewicz, M. V., eds., Cenozoic geology of the Simi Valley area, southern California: Society of Economic Paleontologists and Mineralogists, Pacific Section, Fall Field Trip Volume and Guidebook, p. 173-182.

Blake, G. H., 1991, Review of the Neogene biostratigraphy and stratigraphy of the Los Angeles basin and implications for basin evolution, in Biddle, K. T., ed., Active margin basins: American Association of Petroleum Geologists Memoir 52, p. 135-184. 
Blundell, M. C., 1983, Depositional environments of the Vaqueros Formation, Big Mountain area, Ventura County, California, in Squires, R. L., and Filewicz, M. V., eds., Cenozoic geology of the Simi Valley area, southern California: Society of Economic Paleontologists and Mineralogists, Pacific Section, Fall Field Trip Volume and Guidebook, p. 161-172.

Bohannon, R. G., and Geist, Eric, 1998, Upper crustal structure and Neogene tectonic development of the California Continental Borderland: Geological Society of America Bulletin, v. 110 , p. $779-800$.

California Division of Oil and Gas, 1975, 60th Annual report of the state oil and gas supervisor-1974: California Division of Oil and Gas, Report no. PR06, p. 32.

Calvano, Gino, Lander, E. B., Whistler, D. P., Roeder, M. A., Walsh, S. L., and Wagner, H. M., 2003, Recognition of a major unconformity in the middle Eocene to lower Miocene, nonmarine Sespe Formation, northern Santa Ana Mountains, Orange County, CA: Paleo Bios, v. 23, supplement to no. $1, \mathrm{p} .1$.

Campbell, R. H., and Yerkes, R. F., 1979, Stratigraphic nomenclature of the central Santa Monica Mountains, Los Angeles County, California: U. S. Geological Survey Bullletin 1457-E, 31 p., 3 plates.

Campbell, R. H., Yerkes, R. F., and Wentworth, C. M., 1966, Detachment faults in the central Santa Monica Mountains, California: U. S. Geological Survey Professional Paper 550-C, p. C1-C11.

Campbell, R. H., Blackerby, B. A., Yerkes, R. F., Schoellhamer, J. E., Birkeland, R. W., and Wentworth, C. W., 1996, Geologic map of the Point Dume quadrangle, Los Angeles County, California: U. S. Geological Survey Map GQ-1747, scale $1: 24,000$.

Carey, S. M., and Colburn, I. P., 1978, Late Cretaceous sedimentation in the Santa Monica Mountains, California, in Howell, D. G., and McDougall, K. A., eds., Mesozoic paleogeography of the western United States: Society of Economic Paleontologists and Mineralogists, Pacific Section, p. 547-558.

Castro, M. J., 1975, Mahala field, in Truex, J. N., ed., A tour of the oil fields of the Whittier fault zone, Los Angeles basin, Calif:: American Association of Petroleum Geologists, Society of Exploration Geophysicists, and Society of Economic Paleontologists and Mineralogists, Pacific Sections, Joint Annual Field Trip, April 2, 1975, p. 73-76.

Colburn, I. P., 1973, Stratigraphic relations of the southern California Cretaceous strata, in Colburn, I. P., and Fritsche, A. E., eds., Cretaceous stratigraphy of the Santa Monica Mountains and Simi Hills: Society of Economic Paleontologists and Mineralogists, Pacific Section, Fall Field Trip Guidebook, p. 45-73.

Colburn, I. P., 1996, Stratigraphy and sedimentary structures of the Paleogene successions in the west central Santa Monica Mountains, Los Angeles County, California, in Abbott, P. L., and Cooper, J. D., eds., Field Conference Guide 1996: American Association of Petroleum Geologists, Pacific Section, GB 73, and Society of Economic Paleontologists and Mineralogists, Pacific Section, Book 80, p. 93-116.
Colburn, I. P., West, E. R., and Carey, S. Mc.D., 1981, Conglomerates of the Chatsworth Formation; a discussion of petrology and provenance, in Link, M. H., Squires, R. L., and Colburn, I. P., eds., Simi Hills Cretaceous turbidites, southern California: Society of Economic Paleontologists and Mineralogists, Pacific Section, p. 75-88.

Crouch, J. K., and Suppe, J., 1993, Late Cenozoic tectonic evolution of the Los Angeles basin and inner California borderland; a model for core-complex-like crustal extension: Geological Society of America Bulletin, v. 105, p. 1415-1434.

Crowell, J. C., 1974, Origin of late Cenozoic basins in southern California, in Dickinson, W. R., ed., Tectonics and sedimentation: Society of Economic Paleontologists and Mineralogists Special Publication No. 22, p. 190-204.

Crowell, J. C., 1987, Late Cenozoic basins of onshore southern California; complexity is the hallmark of their tectonic history, in Ingersoll, R. V., and Ernst, W. G., eds., Cenozoic basin development of coastal California: Englewood Cliffs, New Jersey, Prentice-Hall, Inc., Rubey Volume VI, p. 208-241.

Daniel-Lyle, L., 1995, Depositional environment and paleogeography of the lower Miocene Vaqueros Formation, Santa Ana Mountains, California, in Fritsche, A. E., ed., Cenozoic paleogeography of the western United States-II: Society for Sedimentary Geology, Pacific Section, Book 75, p. 9-21.

Daviess, S. N., and Woodford, A. O., 1949, Geology of the northwestern Puente Hills, Los Angeles County, California: U. S. Geological Survey Oil and Gas Investigations Preliminary Map 83, scale 1:12,000.

Davis, T. L., Namson, J., and Yerkes, R. F., 1989, A cross section of the Los Angeles area; seismically active fold and thrust belt, the 1987 Whittier Narrows earthquake, and earthquake hazard: Journal of Geophysical Research, v. 94, p. 9644-9664.

Dibblee, T. W., Jr., 1982, Geology of the Santa Monica Mountains and Simi Hills, southern California, in Fife, D. L., and Minch, J. A., eds., Geology and mineral wealth of the California Transverse Ranges: South Coast Geological Society, Inc., Annual Symposium and Guidebook Number 10, p. 94-130.

Dibblee, T. W., Jr., 1991, Geologic map of the San Fernando and Van Nuys (north 1/2) quadrangles, Los Angeles County, California: Dibblee Geological Foundation, map DF-33, scale 1:24,000.

Dibblee, T. W., Jr., and Ehrenspeck, H. E., 1990, Geologic map of the Point Mugu and Triunfo Pass Quadrangles, Ventura and Los Angeles Counties, California: Dibblee Geological Foundation, map DF-29, scale 1:24,000.

Dickinson, W. R., 1996, Kinematics of transrotational tectonism in the California Transverse Ranges: Geological Society of America Special Paper 305, 46 p.

Durham, D. L., and Yerkes, R. F., 1964, Geology and oil resources of the eastern Puente Hills area, southern California: U. S. Geological Survey Professional Paper 420-B, 62 p.

Durrell, C., 1954, Geology of the central Santa Monica Moun- 
tains, Los Angeles and Ventura Counties, in Jahns, R. H., ed., Geology of southern California: California Division of Mines Bulletin 170, map sheet 8, scale 1:125,000.

Eaton, G. P., 1958, Miocene volcanic activity in the Los Angeles basin, in Higgins, J. W., ed., A guide to the geology and oil fields of the Los Angeles and Ventura regions: American Association of Petroleum Geologists, Pacific Section, p. 55-61.

Flack, M. E., 1993, Depositional environments of the "Topanga Canyon" Formation, the Encinal Tongue of the Rincon Shale, and the Fernwood Tongue of the Sespe Formation, Central Santa Monica Moutains, California, in Weigand, P. W., Fritsche, A. E., and Davis, G. E., eds., Depositional and volcanic environments of middle Tertiary rocks in the Santa Monica Mountains, southern California: Society for Sedimentary Geology, Pacific Section, Book 72, p. 45-74.

Fritsche, A. E., 1993, Middle Tertiary stratigraphic terminology for the Santa Monica Mountains, southern California, in Weigand, P. W., Fritsche, A. E., and Davis, G. E., eds., Depositional and volcanic environments of middle Tertiary rocks in the Santa Monica Mountains, southern California: Society for Sedimentary Geology, Pacific Section, Book 72, p. 1-12.

Fritsche, A. E., 1998, Miocene paleogeography of southwestern California and its implications regarding basin terminology: International Geology Review, v. 40, p. 452-470.

Gaede, V. F., 1969, Prado-Corona oil field: California Division of Oil and Gas Resources, California Oilfields - Summary of Operations, v. 55, no. 1, p. 23-29.

Goodban, F. R., 1958, San Clemente oil field, in Higgins, J. W., ed., A guide to the geology and oil fields of the Los Angeles and Ventura regions: Los Angeles, California, American Association of Petroleum Geologists, Pacific Section, p. 145-148.

Gray, C. H., Jr., 1961, Geology and mineral resources of the Corona South quadrangle: California Division of Mines and Geology Bulletin 178, 120 p.

Hall, E. A., Barker, C. T., and Rutherford, V. E., 1975, Geology of the Torrey Canyon, Oakridge, Santa Susana, South Tapo, and Tapo Ridge oil fields, and the nearby area, Ventura County, California: American Association of Petroleum Geologists, Pacific Section, Spring Field Trip Guidebook No. 40,12 p.

Harris, P. B., 1958, Long Beach Airport pool, in Higgins, J. W., ed., A guide to the geology and oil fields of the Los Angeles and Ventura regions: Los Angeles, California, American Association of Petroleum Geologists, Pacific Section, p. 75-77.

Hauksson, E., and Jones, L. M., 1989, The 1987 Whittier Narrows earthquake sequence in Los Angeles, southern California; seismological and tectonic analysis: Journal of Geophysical Research, v. 94, p. 9569-9589.

Hauksson, E., Jones, L. M., and Hutton, K., 1995, The 1994 Northridge earthquake sequence in California; seismological and tectonic aspects: Journal of Geophysical Research, v. 100, n. B7, p. 12335-12355.

Hazenbush, G. C., and Allen, D. R., 1958, Huntington Beach oil field: California Division of Oil and Gas Resources, California Oilfields-Summary of Operations, v. 44, no. 1, p. 13-25.

Hill, M. L., 1971, Newport-Inglewood zone and Mesozoic subduction, California: Geological Society of America Bulletin, v. 82 , p. 2957-2962.

Hoots, H. W., 1931, Geology of the eastern part of the Santa Monica Mountains, Los Angeles County, California: U. S. Geological Survey Professional Paper 165-C, p. 83-134, map scale $1: 24,000$.

Hornafius, J. S., 1985, Neogene tectonic rotation of the Santa Ynez Range, Western Transverse Ranges, California, suggested by paleomagnetic investigation of the Monterey Formation: Journal of Geophysical Research, v. 90, p. 12503-12522.

Hornafius, J. S., Luyendyk, B. P., Terres, R. R., and Kamerling, M J., 1986, Timing and extent of Neogene tectonic rotation in the western Transverse Ranges, California: Geological Society of America Bulletin, v. 97, p. 1476-1487.

Howard, J. L., 1989, Conglomerate clast populations of the Upper Paleogene Sespe Formation, southern California, in Colburn, I. P., Abbott, P. L., and Minch, J. A., eds., Conglomerates in basin analysis; a symposium dedicated to A. O. Woodford: Society of Economic Paleontologists and Mineralogists, Pacific Section, Book 62, p. 269-280.

Howard, J. L., 2000, Provenance of quartzite clasts in the EoceneOligocene Sespe Formation: paleogeographic implications for southern California and the ancestral Colorado River: Geological Society of America Bulletin, v. 112, p. 16351649.

Howard, J. L., and Lowry, W. D., 1995, Medial Cenozoic paleogeography of the Los Angeles area, southwestern California, and adjacent parts of the United States, in Fritsche, A. E., ed., Cenozoic paleogeography of the western United States-II: Society of Economic Paleontologists and Mineralogists, Pacific Section, Book 75, p. 22-41.

Huftile, G. J., 1988, Structural geology of the Chaffee Canyon oil field, Ventura County, California, in Sylvester, A. G., and Brown, G. C., Santa Barbara and Ventura basins: Ventura, California, Coast Geological Society, Guidebook 64, p. 125-132.

Ingersoll, R. V., and Rummelhart, P. E., 1999, Three-stage evolution of the Los Angeles basin, southern California: Geology, v. 27 , p. 593-596.

Irving, E. M., 1937, Tourmalinization in the vicinity of the Cajalco Tin Mine, near Corona, California [abs.]: Proceedings of the Geological Society of America for 1936, p. 300-301.

Jacobson, J. B., and Lindblom, R. G., 1987, The east Beverly Hills, south Salt Lake and San Vicente fields - examples of urban oil development, Los Angeles, California, in Wright, T., and Heck, R., eds., Petroleum geology of coastal southern California: American Association of Petroleum Geologists, Pacific Section, p., 32-30.

Jones, L. M., Sieh, K. E., Hauksson, E., and Hutton, L. K., 1990, The 3 December 1988 Pasadena, California earthquake; evidence for strike-slip motion on the Raymond fault: Seismological Society of America Bulletin, v. 80, p. 474-482.

Junger, A., and Wagner, H. C., 1977, Geology of the Santa Monica 
and San Pedro Basins, California Continental Borderland: U. S. Geological Survey Miscellaneous Field Studies Map MF-820, 10 p., 5 sheets, scale 1:250,000.

Kaban, M. K., and Mooney, W. D., 2001, Density structure of the lithosphere in the southwestern United States and its tectonic significance: Journal of Geophysical Research, v. 106, p. 721-739.

Kamerling, M. J., and Luyendyk, B. P., 1979, Tectonic rotations of the Santa Monica Mountains region, western Transverse Ranges, California, suggested by paleomagnetic vectors: Geological Society of America Bulletin, v. 90, p. 331-337.

Kamerling, M. J., and Luyendyk, B. P., 1985, Paleomagnetism and Neogene tectonics of the northern Channel Islands, California: Journal of Geophysical Research, v. 90, n. B14, p. 12485-12502.

Kelly, T. S., 1990, Biostratigraphy of Uintan and Duchesnean land mammal assemblages from the middle member of the Sespe Formation, Simi Valley, California: Natural History Museum of Los Angeles County Contributions in Science, Number 419, p. 1-42.

Kew, W. S. W., 1923, Geologic formations of a part of southern California and their correlation: American Association of Petroleum Geologists Bulletin, v. 7, p. 411-420.

Lander, E. B., 1983, Continental vertebrate faunas from the upper member of the Sespe Formation, Simi Valley, California, and the terminal Eocene event, in Squires, R. R., and Filewicz, M. V., eds., Cenozoic geology of the Simi Valley area, southern California: Society of Exploration Paleontologists and Mineralogists, Pacific Section, Fall Field Trip Volume and Guidebook, p., 142-153.

Lander, E. B., 1994, Recalibration and causes of marine regressive-transgressive cycle recorded by middle Eocene to lower Miocene nonmarine Sespe Formation, southern California continental plate margin, in Fritsche, A. E., ed., Sedimentology and paleontology of Eocene rocks in the Sespe Creek area, Ventura County, California: Society for Sedimentary Geology, Pacific Section, Book 74, p. 79-88.

Lander, E. B., Weigand, P. W., Fritsche, A. E., Alderson, J. M., and Iriondo, Alexander, 2003, $\mathrm{New}{ }^{40} \mathrm{Ar} /{ }^{39} \mathrm{Ar}$ age determinations for two tuffs in the Piuma (upper) Member of the continental Sespe Formation, central Santa Monica Mountains, California [abs.]: American Association of Petroleum Geologists, Pacific Section, Conference Program \& Abstracts, May 19-24, Long Beach, p. 37.

Lane, C. L., 1989, Comparison of arenite and conglomerate clast petrology; utility in provenance determinations, southern California, in Colburn, I. P., Abbott, P. L., and Minch, John, eds., Conglomerates in basin analysis; a symposium dedicated to A. O. Woodford: Society of Economic Paleontologists and Mineralogists, Pacific Section, v. 62, p. 255-267.

Lang, H. R., and Dreessen, R. S., 1975, Subsurface structure of the northwestern Los Angeles basin: California Division of Oil and Gas Resources, Technical Papers, Report TP01, p. 15-21.
Langenheim, V. E., and Jachens, R. C., 1996, Gravity data collected along the Los Angeles regional experiment (LARSE) and preliminary model of regional density variations in basement rocks, southern California: U. S. Geological Survey Open File Report 96-682, 25 p.

Levi, S., and Yeats, R. S., 1993, Paleomagnetic constraints on the initiation of uplift on the Santa Susana fault, western Transverse Ranges, California: Tectonics, v. 12, p. 688-702.

Levi, S., and Yeats, R. S., 2001, Crustal fragmentation and Neogene rotations in the east Ventura basin and San Fernando Valley, southern California [abs.]: Geological Society of America, Abstracts with Programs, v. 33, no. 3, p. A-63.

Liddicoat, J. C., 1988, Paleomagnetism of the Zuma Volcanics, Point Dume, Los Angeles County, California: California Geology, v. 41, p. 243-247.

Liddicoat, J. C., 1990, Tectonic rotation of the Santa Ynez Range, California, recorded in the Sespe Formation: Geophysical Journal International, v. 102, p. 739-745.

Liddicoat, J. C., 2001, Paleomagnetism of the Sespe Formation (Eocene-Oligocene), Ventura and Santa Barbara Counties, California, in Prothero, D. R., ed., Magnetic stratigraphy of the Pacific Coast Cenozoic: Society for Sedimentary Geology, Pacific Section, Book 91, p. 144-153.

Link, M. H., and Dibblee, T. W., Jr., 1987, Field trip guide to the Ventura Basin area, in Link, M. H., ed., Ventura basin; geologic introduction and field trip guidebook: American Association of Petroleum Geologists, Pacific Section, October 17-18, 1987, p. 23-36.

Loel, W., and Corey, W. H., 1932, The Vaqueros Formation, Lower Miocene of California: University of California Publications, Bulletin of Department of Geological Sciences, v. 22, no. 3, p. 31-410.

Lucas, S. G., Whistler, D. P., and Wagner, H. M., 1997, Giant Entelodont (Mammalia Artiodactyla) from the early Miocene of southern California: Natural History Museum of Los Angeles County, Contributions in Science, no. 466, p. 1-9.

Ludtke, Josh, and Prothero, D. R., 2003, Magnetic stratigraphy of the Eocene-Oligocene-Miocene Sespe-Vaqueros Formations, northern Orange County, CA: Paleo Bios, v. 23, supplement to no. 1, p. 5.

Luyendyk, B. P., 1990, Neogene-age fault slip in the continental transform zone in Southern California: Annales Tectonicae, Special Issue v. IV, p. 24-34.

Luyendyk, B. P., 1991, A model for Neogene crustal rotations, transtension, and transpression in southern California: Geological Society of America Bulletin, v. 103, p. 15281536.

Luyendyk, B. P., and Hornafius, J. S., 1987, Neogene crustal rotations, fault slip, and basin development in southern California, in Ingersoll, R. V., and Ernst, W. G., eds., Cenozoic basin development of coastal California: Englewood Cliffs, New Jersey, Prentice-Hall, Inc., Rubey Volume VI, p. 260-283.

Luyendyk, B. P., Gans, P. B., and Kamerling, M J., 1998, ${ }^{40} \mathrm{Ar} /{ }^{39} \mathrm{Ar}$ geochronology of southern California Neogene volcanism, in Weigand, P. W., ed., Contributions to the geology of the 
northern Channel Islands, southern California: American Association of Petroleum Geologists, Pacific Section, MP45, p. 9-35.

Mason, M. A., and Swisher, C. C., III, 1989, New evidence for the age of the South Mountain local fauna, Ventura County, California: Natural History Museum of Los Angeles County Contributions in Science, no. 410, 9 p.

Mayer, L., 1991, Central Los Angeles basin; subsidence and thermal implications for tectonic evolution, in Biddle, K. T., ed., Active margin basins: American Association of Petroleum Geologists Memoir 52, p. 185-195.

McCulloh, T. H., 1960, Gravity variations and the geology of the Los Angeles basin, California: U. S. Geological Survey Professional Paper 400-B, p. B320-B325.

McCulloh, T. H., Beyer, L. A., and Enrico, R. J., 2000, Paleogene strata of the eastern Los Angeles basin, California; paleogeography and constraints on Neogene structural evolution: Geological Society of America Bulletin, v. 112, p. 1155-1178.

McCulloh, T. H., Beyer, L. A., and Morin, R. W., 2001, Mountain Meadows Dacite: Oligocene intrusive complex that welds together the Los Angeles Basin, northwestern Peninsular Ranges, and central Transverse Ranges, California: U. S. Geological Survey Professional Paper 1649, 34 p.

McCulloh, T. H., Fleck, R. J., Denison, R. E., Beyer, L. A., and Stanley, R. G., 2002, Age and tectonic significance of volcanic rocks in the northern Los Angeles Basin, California: U. S. Geological Survey Professional Paper 1669, 24 p.

McMurdie, D. S., Taylor, J. C., and Truex, J. N., compilers, 1973, Contours on top Miocene, southern Los Angeles basin, in Metropolitan oil fields and their environmental impact: American Association of Petroleum Geologists, Society of Exploration Paleontologists and Mineralogists, and Society of Exploration Geophysicists, Pacific Sections, Guidebook Trip 2, approximate scale 1:111,600.

Merriam, C. W., 1941, Fossil turritellas from the Pacific Coast region of North America: University of California Publications, Bulletin of the Department of Geological Sciences, v. 26 , no. 1, p. 1-214.

Minch, J. A., Howard, J. L., and Belyea, R. R., 1989, Sespe Formation conglomerates in the northern Santa Ana and Santa Monica Mountains; a field trip guide, in Colburn, I. P., Abbott, P. L., and Minch, J., eds., Conglomerates in basin analysis; a symposium dedicated to A. O. Woodford: Society of Economic Paleontologists and Mineralogists, Pacific Section, book 62, p. 301-312.

Molnar, P., and Gipson, J. M., 1994, Very long baseline interferometry and active rotations of crustal blocks in the Western Transverse Ranges, California: Geological Society of America Bulletin, v. 106, p. 594-606.

Morris, L. K., Lund, S. P., and Bottjer, D. J., 1986, Palaeolatitude drift history of displaced terranes in southern and Baja California: Nature, v. 321, p. 844-847.

Nagle, H. E., and Parker, E. S., 1971, Future oil and gas potential of onshore Ventura basin, California, in Cram, I. H., ed., Future petroleum provinces of the United States - their geology and potential: American Association of Petroleum
Geologists, Memoir 15, p. 254-297.

Nicholson, C., Sorlien, C. C., Atwater, T., Crowell, J. C., and Luyendyk, B. P., 1994, Microplate capture, rotation of the western Transverse Ranges, and initiation of the San Andreas transform as a low-angle fault system: Geology, v. 22, p. 491-495.

Nourse, J. A., Weigand, P. W., and Hazelton, G. B., 1998, Igneous and tectonic response of the eastern San Gabriel Mountains to Neogene extension and rotation of the Transverse Ranges block, in Behl, R. J., ed., Guidebook to field trip No. 10, 94th Annual Meeting, Cordilleran Section of the Geological Society of America, p. 10-1 to 10-15.

Oakeshott, G. B., 1958, Geology and mineral deposits of San Fernando Quadrangle, Los Angeles County, California: California Division of Mines Bulletin 172, 147 p.

Oborne, J. G., 1993, Stratigraphy and depositional environments of the Vaqueros Formation, central Santa Monica Mountains, California, in Weigand, P. W., Fritsche, A. E., and Davis, G. E., eds., Depositional and volcanic environments of middle Tertiary rocks in the Santa Monica Mountains, southern California: Society for Sedimentary Geology, Pacific Section, Book 72, p. 25-44.

Oskin, Michael, Sieh, Kerry, Rockwell, T., Miller, G., Guptill, P., Curtis, M., McAardle, S., and Elliot, P., 2000, Active parasitic folds on the Elysian Park anticline; implications for seismic hazard in central Los Angeles, California: Geological Society of America Bulletin, v. 112, p. 693-707.

Paschall, R. H., and Off, T., 1959, San Gabriel fault problem in the Castaic area: Ventura, California, Coast Geological Society, Occasional Papers no. 1, p. 1-8.

Paschall, R. H., and Off, T., 1961, Dip-slip versus strike-slip movement on the San Gabriel fault, southern California: American Association of Petroleum Geologists Bulletin, v. 45, p. 1941-1956.

Pinter, Nicholas, Lueddecke, S. B., Keller, E. A., and Simmons, K. R., 1998, Late Quaternary slip on the Santa Cruz Island fault, California: Geological Society of America Bulletin, v. 110, p. 711-722.

Pratt, T. L., Dolan, J. F., Odum, J. K., Stephenson, W. J., Williams, R. A., and Templeton, M. E., 1998, Multiscale seismic imaging of active fault zones for hazard assessment: a case study of the Santa Monica fault zone, Los Angeles, California: Geophysics, v. 63, p. 479-489.

Prothero, D. R., and Donohoo, L. L., 2001, Magnetic stratigraphy of the lower Miocene (early Hemingfordian) Sespe-Vaqueros Formations, Orange County, California, in Prothero, D. R., ed., Magnetic Stratigraphy of the Pacific Coast Cenozoic: Society for Sedimentary Geology, Pacific Section, Book 91, p. 242-253.

Prothero, D. R., and Lopez, R. A., 2001, Magnetic stratigraphy and tectonic rotation of the upper Paleocene Silverado Formation, Orange, County, California: in Prothero, D. R., ed., Magnetic Stratigraphy of the Pacific Coast Cenozoic: Society for Sedimentary Geology, Pacific Section, Book 91, p. 27-36.

Prothero, D. R., Howard, J. L., and Dozier, T. H. H., 1996, Stratigraphy and paleomagnetism of the Upper Middle Eocene 
to Lower Miocene (Uintan to Arikareean) Sespe Formation, Ventura County, California, in Prothero, D. R., and Emry, R. J., eds., The Terrestrial Eocene-Oligocene transition in North America: Cambridge University Press, p. 171-188.

Redin, T., 1991, Oil and gas production from submarine fans of the Los Angeles basin, in Biddle, K. T., ed., Active margin basins: American Association of Petroleum Geologists Memoir 52, p. 239-259.

Rumelhart, P. E., and Ingersoll, R. V., 1997, Provenance of the Upper Miocene Modelo Formation and subsidence analysis of the Los Angeles basin, southern California; implications for paleotectonic and paleogeographic reconstructions: Geological Society of America Bulletin, v. 109, p. 885899.

Schneider, C. L., Hummon, C., Yeats, R. S., and Huftile, G. L., 1996, Structural evolution of the northern Los Angeles basin, California, based on growth strata: Tectonics, v. 15, p. 341-355.

Schoellhamer, J. E., and Woodford, A. O., 1951, The floor of the Los Angeles basin, Los Angeles, Orange, and San Bernardino Counties, California: U. S. Geological Survey Oil and Gas Investigations Map OM-117.

Schoellhamer, J. E., Vedder, J. G., Yerkes, R. F., and Kinney, D. M., 1981, Geology of the northern Santa Ana Mountains, California: U. S. Geological Survey Professional Paper 420-D, 109 p.

Seeber, Leonardo, and Sorlien, C. C., 2000, Listric thrusts in the western Transverse Ranges, California: Geological Society of America Bulletin, v. 112, p. 1067-1079.

Seedorf, D. C., 1983, Upper Cretaceous through Eocene subsurface stratigraphy, Simi Valley and adjacent regions, California, in Squires, R. L., and Filewicz, M. V., eds., Cenozoic geology of the Simi Valley area, southern California: Society of Economic Paleontologists and Mineralogists, Pacific Section, volume and guidebook, p. 109-128.

Shaw, J. H., and Shearer, P. M., 1999, An elusive blind-thrust fault beneath metropolitan Los Angeles: Science, v. 283, p. 1516-1518.

Shaw, J. H., and Suppe, J., 1996, Earthquake hazards of active blind-thrust faults under the central Los Angeles basin, California: Journal of Geophysical Research, v. 101, no. B4, p. 8623-8642.

Shelton, J. S., 1954, Glendora volcanic rocks, Los Angeles basin, California: Geological Society of America Bulletin, v. 66, p. 45-90.

Shields, K. E., 1978, Faults along the northwestern margin of the San Fernando Valley, Los Angeles County, California, in Lamar, D. L., field trip chairman, Geologic Guide and engineering geology case histories, Los Angeles Metropolitan Area: Association of Engineering Geologists, First Annual Section Conference, p. 44-52.

Simonson, R. R., 1937, Conglomerates of the Sespe and Topanga formations of Dry Canyon quadrangle, Santa Monica Mountains, California [abs.]: Proceedings of the Geological Society of America for 1936, p. 304-305.

Smith, J. T., 1991, Cenozoic giant pectinids from California and the Tertiary Caribbean Province; Lyropecten, "Macrochlamis,"
Vertipecten, and Nodipecten species: U. S. Geological Survey Professional Paper 1391, 155 p., 38 plates.

Soper, E. K., 1938, Geology of the central Santa Monica Mountains: California Division of Mines, Journal of Mines and Geology Report, v. 34, p. 131-180.

Sorensen, S., 1985, Petrologic evidence for Jurassic, island-arclike basement rocks in the southwestern Transverse Ranges and California Continental Borderland: Geological Society of America Bulletin, v. 96, p. 997-1006.

Sorlien, C. C., Nicholson, Craig, and Luyendyk, B. P., 1999, Miocene extension and post-Miocene transpression offshore of south-central California: U. S. Geological Survey Bulletin 1995-Y, 38 p.

Sorlien, C. C., Gratier, J.-P., Luyendyk, B. P., Hornafius, J. S., and Hopps, T. E., 2000, Map restoration of folded and faulted late Cenozoic strata across the Oak Ridge fault, onshore and offshore Ventura basin, California: Geological Society of America Bulletin, v. 112, p. 1080-1090.

Stock, C., 1948, Pushing back the history of land mammals in western North America: Geological Society of America Bulletin, v. 59, p. 327-332.

Stuart, C. J., 1976, Source terrane of the San Onofre Breccia-preliminary notes, in Howell, D. G., ed., Aspects of the geologic history of the California Continental Borderland: American Associate of Petroleum Geologists, Pacific Section, Miscellaneous Publication 24, p. 309-325.

Stuart, C. J., 1979, Middle Miocene paleogeography of coastal southern California and the California Borderland-evidence from schist-bearing sedimentary rocks, in Armentrout, J. M., Cole, M. R., and TerBest, H., Jr., Cenozoic paleogeography of the western United States: Society of Economic Paleontologists and Mineralogists, Pacific Section, Pacific Coast Paleogeography Symposium 3, p. $29-44$.

Taylor, G. E., 1984, Depositional environments of the Eocene through Oligocene Sespe Formation in the northern Simi Valley area, Ventura County, California: California State University Northridge, M. S. thesis, 74 p.

Truex, J. N., 1976, Santa Monica and Santa Ana Mountains - relation to Oligocene Santa Barbara basin: American Association Petroleum Geologists Bulletin, v. 60, p. 65-86.

Tsutsumi, H., Yeats, R. S., and Huftile, G. J., 2001, Late Cenozoic tectonics of the northern Los Angeles fault system: Geological Society of America Bulletin, v. 113, p. 454-468.

Turner, D. L., and Campbell, R. H., 1979, Age of the Conejo Volcanics, in Yerkes, R. F., and Campbell, R. H., eds., Stratigraphic nomenclature of the central Santa Monica Mountains, Los Angeles County, California: U. S. Geological Survey Bulletin 1457-E, p. E18-E22.

Vedder, J. G., 1973, Geologic framework and correlation of Miocene rocks in the Caliente Range: Society of Economic Paleontologists and Mineralogists, Pacific Section, Field Trip 2 Guidebook, p. 42-53.

Vedder, J. G., 1975, Revised geologic map, structure sections, and well table, San Joaquin Hills_-San Juan Capistrano area, California: U. S. Geological Survey Open-File Report 75552, 3 sheets, scale 1:24,000. 
Vedder, J. G., and Howell, D. G., 1976, Review of the distribution and tectonic implications of Miocene debris from the Catalina Schist, California Continental Borderland and adjacent coastal areas, in Howell, D. G., ed., Aspects of the California Continental Borderland: American Association of Petroleum Geologists, Pacific Section, Miscellaneous Publication 24, p. 326-340.

Vedder, J. C., Yerkes, R. F., and Schoellhamer, J. E., 1957, Geologic map of the San Joaquin Hills_-San Juan Capistrano area, Orange County, California: U. S. Geological Survey Oil and Gas Investigations Map OM-193, scale $1: 24,000$.

Weber, R. H., Jr., Cleveland, G. B., Kahle, J. E., Kiessling, E. F., Miller, R. V., Mills, M. F., and Morton, D. M., 1973, Geology and mineral resources study of southern Ventura County, California: California Division of Mines and Geology Preliminary Report 14, 102 p., map scale 1:48,000.

West, J. C., and Redin, T. W., 1991a, Correlation section across eastern Los Angeles basin from San Pedro Bay to San Gabriel Mts.: American Association of Petroleum Geologists, Pacific Section, scale 1:48,000 (horizontal), 1:12,000 (vertical).

West, J. C., and Redin, T. W., 1991b, Correlation section across northern Los Angeles basin from Santa Monica Bay to Prado Flood Control Basin: American Association of Petroleum Geologists, Pacific Section, scale 1:48,000 (horizontal), 1:12,000 (vertical).

Whistler, D. P., and Lander, E. B, 2003, New late Uintan to early Hemingfordian land mammal assemblages from the undifferentiated Sespe and Vaqueros formations, Orange County, and from the Sespe and equivalent marine formations in Los Angeles, Santa Barbara, and Ventura Counties, southern California, in Flynn, L. J., ed., Vertebrate fossils and their context - contributions in honor of Richard H. Tedford: Bulletin of the American Museum of Natural History, v. 13, no. 279, p. 231-268.

Wilde, Melita, and Stock, Joann, 1997, Compression directions in southern California (from Santa Barbara to Los Angeles basin) obtained from borehole breakouts: Journal of Geophysical Research, v. 102, p. 4969-4983.

Woodford, A. O., and Bailey, T. L., 1928, Northwestern continuation of the San Onofre Breccia: University of California Publications, Bulletin of the Department of Geological Sciences, v. 17, no. 5, p. 187-191.

Woodford, A. O., and Gander, Craig, 1980, Early Tertiary conglomerates of the Santa Ana Mountains, California: Journal of Sedimentary Petrology, v. 50, p. 743-753.

Woodford, A. O., Schoellhamer, J. E., Vedder, J. G., and Yerkes, R. F., 1954, Geology of the Los Angeles basin, in Jahns, R. F., ed., Geology of Southern California: California Division of Mines Bulletin 170, Chapter 2, p. 65-81.

Woodford, A. O., Welday, E. E., and Merriam, R., 1968, Siliceous tuff clasts in the upper Paleogene of southern California: Geological Society of America Bulletin, v. 79, p. 14611486.

Woodford, A. O., McCulloh, T. H., and Schoellhamer, J. E., 1972, Paleogeographic significance of metatuff boulders in middle
Tertiary strata, Santa Ana Mountains, California: Geological Society of America Bulletin, v. 83, p. 3433-3436.

Wright, T. L., 1991, Structural geology and tectonic evolution of the Los Angeles basin, California, in Biddle, K. T., ed., Active margin basins: American Association of Petroleum Geologists Memoir 52, p. 35-134.

Wright, T. L., Parker, E. S., and Erickson, R. C., 1973, Stratigraphic evidence for timing and nature of late Cenozoic deformation in Los Angeles region, California [abs.]: American Association of Petroleum Geologists Bulletin, v. 57, p. 813.

Yeats, R. S., 1973, Newport-Inglewood fault zone, Los Angeles basin, California: American Association of Petroleum Geologists Bulletin, v. 57, p. 117-135.

Yeats, R. S., 1974, Newport-Inglewood fault zone, Los Angeles basin, California; reply: American Association of Petroleum Geologists Bulletin, v. 58, p. 884-888.

Yeats, R. S., 1976, Extension versus strike-slip origin of the Southern California Borderland, in Howell, D. G., ed., Aspects of the geologic history of the California Continental Borderland: American Association of Petroleum Geologists, Pacific Section, Miscellaneous Publication 24, p. 455-485.

Yeats, R. L., 1983, Simi; a structural essay, in Squires, R. R., and Filewicz, M. V., eds., Cenozoic geology of the Simi Valley area, southern California: Society of Exploration Paleontologists and Mineralogists, Pacific Section, Fall Field Trip and Guidebook, p. 233-240.

Yeats, R. S., 1987, Late Cenozoic structure of the Santa Susana fault zone: U. S. Geological Survey Professional Paper 1339, p. 137-160.

Yeats, R. S., and Beall, J. M., 1991, Stratigraphic controls of oil fields in the Los Angeles basin; a guide to migration history, in Biddle, K. T., ed., Active margin basins: American Association of Petroleum Geologists Memoir 52, p. 221-237.

Yerkes, R. F., 1957, Volcanic rocks of the El Modeno area, Orange County, California: U. S. Geological Survey Professional Paper 274-L, p. 313-334.

Yerkes, R. F., 1972, Geology and oil resources of the western Puente Hills area, southern California: U. S. Geological Survey Professional Paper 420-C, 63 p.

Yerkes, R. F., and Campbell, R. H., 1979, Stratigraphic nomenclature of the central Santa Monica Mountains, Los Angeles County, California: U. S. Geological Survey Bulletin 1457-E, p. E1-E29.

Yerkes, R. F., and Campbell, R. H., 1980, Geologic map of eastcentral Santa Monica Mountains, Los Angeles County, California: U. S. Geological Survey Miscellaneous Investigations Series Map I-1146, scale 1: 24,000.

Yerkes, R. F., and Lee, W. H. K., 1979, Late Quaternary deformation in the Western Transverse Ranges: U. S. Geological Survey Circular 799-B, p. 27-37.

Yerkes, R. F., McCulloh, T. H., Schoellhamer, J. E., and Vedder, J. G., 1965, Geology of the Los Angeles basin - an introduction: U. S. Geological Survey Professional Paper 420-A, $57 \mathrm{p}$. 
Petroleum exploration drill holes that provide control on the total thickness of Vaqueros and Sespe Formations (differentiated and undifferentiated) or equivalents

\begin{tabular}{|c|c|c|c|c|c|c|c|}
\hline $\begin{array}{l}\text { Map } \\
\text { symbol }\end{array}$ & $\begin{array}{l}\text { Original operator, } \\
\text { lease name \& well number }\end{array}$ & $\begin{array}{c}\text { Section } \\
\text { Township, Range } \\
\text { (S. B. B. \& M.) }\end{array}$ & $\begin{array}{l}\text { Latitude (N.) } \\
\text { Longitude (W.) } \\
\text { (degrees) }\end{array}$ & $\begin{array}{l}\text { Elevation } \\
m(\mathrm{ft} .)^{2}\end{array}$ & $\begin{array}{l}\text { Total depth } \\
\mathrm{m}(\mathrm{ft} .)\end{array}$ & $\begin{array}{l}\text { Drill depths of stratigraphic } \\
\text { boundaries, feet. }\end{array}$ & $\begin{array}{c}\text { Sources of information and } \\
\text { comments }\end{array}$ \\
\hline
\end{tabular}

Southeast sector, figure 3

\section{Continental Oil Co.}

Anaheim No. 4-1

Draucker, C. D.

Draucker No. 1

Gill and Associates

Forster No. 1

Gill and Associates

Krum No. 1

Godfrey, A. L., Drill Co.

5 Botiller No. 1

Great Amer. Petrol. Co.

6 Gapco No. B-

Humble Oil Co.

7 O'Neill No. B-

Marcell, Douglas

Puente Hills No. 1

Morton and Sons

El Toro No. 14-1

Morton and Sons

10 Irvine No. 55-1
T.4 S., R. 10 W.

Sec. 28

T.3 S., R.7 W.

T. 8 S., R. 8 W.

T.8 S., R.7 W.

Sec. 29

T.3 S., R.7 W.

Sec. 18

T.2 S., R. 8 W.

Sec. 25

T.6 S., R. 8 W.

Sec. 31

T.2 S., R.8 W.

Sec. 14

T.6 S., R.8 W.

Block 55

Irvine Ranch

Survey
33.8497

117.9474

43

$(142)$

3,255

$(10,679)$

Sespe 8,680 to 9,220; overlain by

Topanga Fm.; rests on Eocene.

1,481 Sespe 2,625 to 2,985; overlain by

$(4,858) \quad$ Puente Fm.; rests on Santiago Fm.

Vaqueros and Sespe 4,000 to 5,050;

overlain by Topanga Fm.; rests on

$(6,550)$ Santiago Fm.

Vaqueros and Sespe 2,670 to 3,760; overlain by Topanga (?); rests on

$(7,117)$ Santiago Fm

117.6440

$(612)$

[kb]

1,455

$(4,775)$

Sespe 0 to 1,840; top eroded; rests on Santiago Fm.

958 Sespe 2,600 to 3,142; may have

$(3,142) \quad$ reached granitic rock.

Vaqueros and Sespe 2,000? to

1,581 3,470; overlain by Topanga (?);

$(5,187)$ rests on Santiago Fm.

117.6720

$(529)$

[kb]

958

$(3,142)$

Sespe 5,158 to 5,800 ; overlain by

33.9525

117.7503

$(1,425)$

[?]

33.6561

117.6841

180

$(591)$
$[?]$

1,990

$(6,528)$

Vaqueros and Sespe 1,150 \pm to

$2,100 \pm$; overlain by Topanga (?)

58

33.6193

117.8759
2,873

$(9,427)$
Sespe 6,530 to $8,550 \pm$; overlain by

Topanga and San Onofre Breccia
West and Redin (1991a).

Gaede (1969); McCulloh and others (2000).

Vedder (1975).

Vedder (1975).

Schoellhamer and others (1981, Plate 2).

Durham and Yerkes (1964, Table 4)

Vedder (1975).

Durham and Yerkes (1964, Table 4).

Vedder (1975).

Vedder (1975). 
Patton Oil Co.

11 Three Corners No. 1

Pomona Oil Co.

12 No. 1

Rubicon Oil Co.

13 Wilcox No.

Santa Fe Minerals Co. (or Casex Co.)

14 Government No. 165-1

\section{Shell Oil Co.}

15 Irvine One No. 44-166

\section{Shell Oil Co.}

6. Puente Corehole No. 4

Shell Oil Co.

17 Irvine Corehole No. 8

Shoreline Oil Co.

18 Pinkerton No. 1

Standard Oil Co. of Calif.

19 Murphy Coyote No. 373

Stella, E. F., Trustee

20 Kraemer-Backs No. 2

The Texas Co.

Buena Park Community

21 No. A-13-1
T.2 S., R.8 W.

33.9838

117.7314

216

S., R.8 W.

33.9841

Sec. 19

T.2 S., R.8 W.

117.7632

Sec. 6

T.4 S., R.8 W.

33.8563

117.7623

Sec. 17

T.3 S., R.7 W.

33.9072

117.6356

Sec. 11

T.7 S., R.9 W.

33.5743

117.7939

Sec. 18

T.2 S., R.8 W.

Block 102

Irvine Ranch

Survey

Sec. 5

T.5 S., R.9 W.

33.7668
117.8402

33.9930

117.7541

33.6769

117.7918

Sec. 18

T.3 S., R.10 W.

Sec. 33

T.2 S., R. 8 W.

Sec. 8

T.4 S., R. 10 W.

33.9555

291

$(955)$
[?]

33.8431

117.9527
(110)

[?]

50

(165)

[df]

[?]

335

$(1,100)$

137

(450)

152

(498)

kb]

(884)

[df]

269

$(884)$
[gr]

4

?]

$(4,715)$

1,105

$(3,625)$

1,576

$(5,169)$

1,928

$(6,325)$

1,826

$(5,991)$

2,995

930

437
960

$(3,151)$

$(9,826)$

$(3,052)$

)

to 2,550; overlain by alluvium; rests on

Santiago Fm.

"Vaqueros and Sespe 1,816 to 2,500 \pm "; overlain by U. Pliocene; rests on Eocene.

Sespe 9,535 to 10,690 ; overlain by

1,594

$(5,231)$

Sespe 3,835 to 4,400 ; overlain by Topanga; rests on Eocene.
41

[kb]
2,736

$(8,977)$
Sespe 8,080 to 8,450 ; overlain by Topanga; rests on Eocene.
Durham and Yerkes (1964, Table 4).

Durham and Yerkes (1964, Table 4).

Schoellhamer and others ( 1981, p. D74).

USGS, California Division of Oil, Gas and Geothermal files;

operator data.

Vedder (1975).

Durham and Yerkes (1964, Table 4).

Vedder (1975).

Schoellhamer and others (1981, p. D76).

California Division of Oil, Gas and Geothermal Resources (1975, p. 32); T. L. Wright, oral communication (1994); USGS files.

Durham and Yerkes (1964, Table 4), McCulloh and others (2000).

West and Redin (1991a) 
I I ie iexas uu.

O'Neill Estate (NCT-1)

No. 1

3.

\section{Atlantic Oil Co.}

24

Nettleship No. 1

Havenstrite Oil Co

25

Tapo No. 1

Occidental Petrol. Corp.

USL No. 83X-2

Standard Oil Co. of Calif.

Austin No. 1

The Superior Oil Co.
Sec. 22

T.8 S., R.7 W.

T.3 S., R. 8 W.
33.4637

117.5909
I $\angle U$

(394)

[kb]
2,147

$(7,044)$
Sespe 1,020 to 2,520; overlain by

San Onofre Breccia; rests on Eocene.

354

$117.6730 \quad$ [df]

1,517 $(4,977)$

Sespe 3,820 to 4,210 ; overlain by Topanga; rests on Eocene.

Northwest sector, figure 4

$\begin{array}{lll}34.1339 & (1,100) & 1,096\end{array}$

[kb] $\quad(3,595) \quad 2,700-3,350$; rests on Eocene.

$\begin{array}{llll}\text { Sec. } 13 & 34.3461 & (1,938) & 2,559\end{array}$

$\begin{array}{lllll}\text { T.3 N., R.18 W. } & 118.7131 & {[\mathrm{~kb}]} & (8,394) & \text { Las Llajas Fm. }\end{array}$

[kb] $\quad(8,500)$

Eroded Vaqueros at surface rests unconformably on Sespe; Sespe transition to marine Eocene Las Llaja: Fm. at about 6,500.

$384 ?$

Sec. 11

34.1019

118.6344

$(1,260 ?)$

[?]

763

763

Sespe from erosional surface to

1,250; rests on "Martinez shale".

\section{Sec. 13}

34.0853

T.1 S., R.21 W.

119.0384

\section{3}

(44)

[kb]

1,156

$(3,792)$

Vaqueros equivalent at surface; Sesp Fm. rests on Paleogene at 3,030.

By correlation with other nearby well: Vaqueros thickness is $1,000 \pm$ and Se thickness is 6,745; Sespe 3,650 to

Union Oil Co. of California
Torrey No. 92
Sec. 5

T.3 N., R.18 W.
34.3733

118.7845

572
$(1,877)$

[rt]
4,569

$(14,989)$
10,285 \pm ; Torrey fault at 3,650; Llaje

Fm. beneath Sespe. 
Palinspastic reconstruction, figure 7

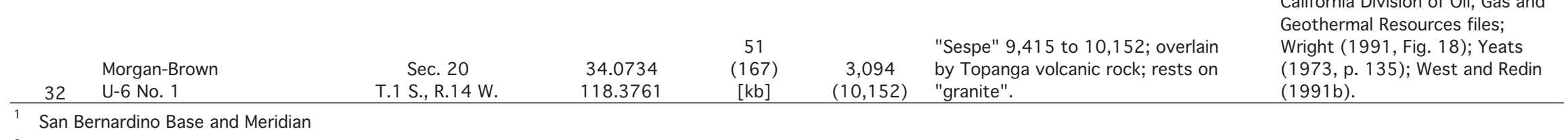

San Bernardino Base and Meridian

2 Depth datum: kb, rt, df, gr = kelly bushing, rotary table, derrick floor, ground level, respectively. 


\section{APPENDIX 2}

Petroleum exploration drill holes deep enough to indicate the presence of Vaqueros and/or Sespe Formations (differentiated and undifferentiated) but failing to provide thickness control

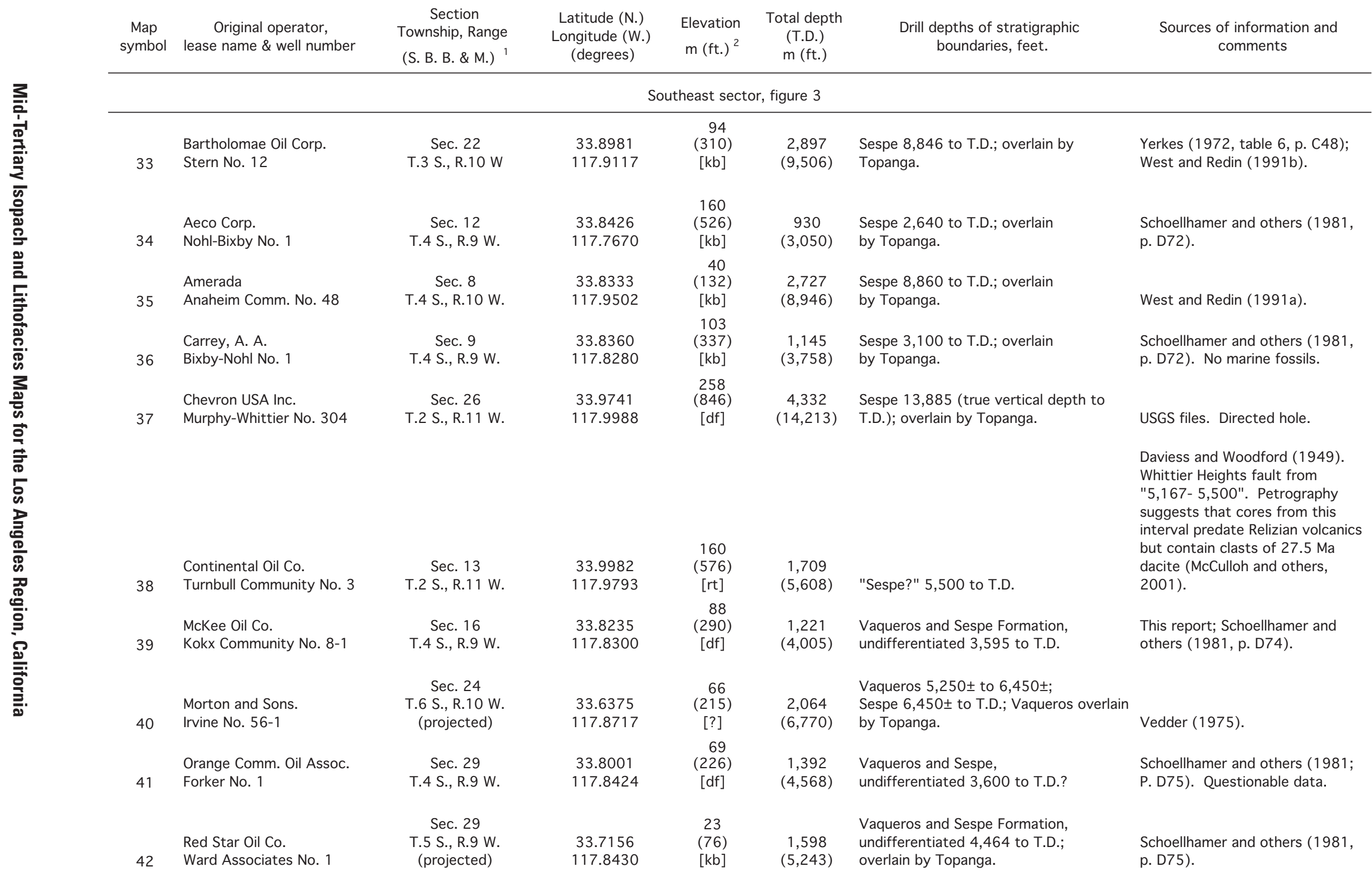




\begin{tabular}{|c|c|c|c|c|c|c|c|c|}
\hline & 43 & $\begin{array}{l}\text { Richfield Oil Corp. } \\
\text { Edwards No. } 1\end{array}$ & $\begin{array}{c}\text { Sec. } 15 \\
\text { T.3 S., R.10 W. }\end{array}$ & $\begin{array}{c}33.9054 \\
117.9195\end{array}$ & $\begin{array}{c}98 \\
(322) \\
{[\mathrm{kb}]}\end{array}$ & $\begin{array}{c}2,923 \\
(9,591)\end{array}$ & $\begin{array}{l}\text { Sespe } 9,546 \text { to T.D.; overlain } \\
\text { by "Topanga (?)". }\end{array}$ & Yerkes (1972, table 6, p. C46). \\
\hline \multirow{13}{*}{$\begin{array}{l}\frac{D}{0} \\
\frac{\mathbb{0}}{2} \\
\frac{\bar{x}}{x}\end{array}$} & 44 & $\begin{array}{l}\text { Shell Oil Co. } \\
\text { Harbeson No. } 1\end{array}$ & $\begin{array}{c}\text { Sec. } 9 \\
\text { T.4 S., R. } 10 \text { W. }\end{array}$ & $\begin{array}{c}33.8367 \\
117.9353\end{array}$ & $\begin{array}{c}43 \\
(141) \\
{[\mathrm{df}]}\end{array}$ & $\begin{array}{c}2,624 \\
(8,608)\end{array}$ & $\begin{array}{l}\text { "Vaqueros" (?) 8,255 to T.D.; } \\
\text { overlain by Topanga. }\end{array}$ & $\begin{array}{l}\text { Yeats and Beall (1991, fig. } 2 \text { G } \\
\text { and appendix); USGS file data } \\
\text { from operator. }\end{array}$ \\
\hline & 45 & $\begin{array}{l}\text { Shell Oil Co. } \\
\text { Irvine Four No. } 51-130 \\
\text { original hole }(\mathrm{OH}) \& \text { redrill } \\
\text { (RD) }\end{array}$ & $\begin{array}{c}\text { Sec. } 5 \\
\text { T.7 S., R.9 W. }\end{array}$ & $\begin{array}{c}33.5959 \\
117.8485\end{array}$ & $\begin{array}{c}116 \\
(381) \\
{[\mathrm{gr}]}\end{array}$ & $\begin{array}{c}1,960 \\
(6,431) \mathrm{OH} \\
2,756 \\
(9,043) \mathrm{RD}\end{array}$ & $\begin{array}{l}\text { Original hole: Sespe } 5,950 \pm \text { to T.D; } \\
\text { overlain by Topanga. Redrill: Sespe } \\
7,100 \text { to } 7,630 \text {; underlain by Santiago } \\
\text { Formation(?); intrusive diabase above. }\end{array}$ & Vedder (1975). Directed hole. \\
\hline & 46 & $\begin{array}{l}\text { Shell Oil Co. } \\
\text { Moulton No. } 88-4\end{array}$ & $\begin{array}{c}\text { Sec. } 4 \\
\text { T.7 S., R. } 8 \text { W. }\end{array}$ & $\begin{array}{c}33.5856 \\
117.7118\end{array}$ & $\begin{array}{c}76 \\
(248) \\
{[\mathrm{df}]}\end{array}$ & $\begin{array}{c}1,209 \\
(3,967)\end{array}$ & $\begin{array}{l}\text { Vaqueros } 1,920 \pm \text { to } 2,670 \pm \\
\text { Sespe } 2,670 \pm \text { to T.D. }\end{array}$ & Vedder (1975). \\
\hline & 47 & $\begin{array}{l}\text { Standard Oil Co. of Calif. } \\
\text { Emery No. } 87\end{array}$ & $\begin{array}{c}\text { Sec. } 13 \\
\text { T.3 S., R. } 11 \text { W. }\end{array}$ & $\begin{array}{c}33.9047 \\
117.9807\end{array}$ & $\begin{array}{c}60 \\
(196) \\
{[\mathrm{df}]}\end{array}$ & $\begin{array}{c}3,359 \\
(11,020)\end{array}$ & $\begin{array}{l}\text { Sespe } 10,075 \text { to T.D.; overlain } \\
\text { by volcanic rocks. }\end{array}$ & Yerkes (1972, table 6, p. C53). \\
\hline & 48 & $\begin{array}{l}\text { Standard Oil Co. of Calif. } \\
\text { Emery No. } 92\end{array}$ & $\begin{array}{c}\text { Sec. } 13 \\
\text { T.3 S., R. } 11 \text { W. }\end{array}$ & $\begin{array}{c}33.9034 \\
117.9768\end{array}$ & $\begin{array}{c}132 \\
(433) \\
{[\mathrm{df}]}\end{array}$ & $\begin{array}{c}3,672 \\
(12,048)\end{array}$ & $\begin{array}{l}\text { Sespe } 10,800 \text { to T.D.; faulted } \\
\text { against Topanga at } 10,800 .\end{array}$ & Yerkes (1972, table 6, p. C53). \\
\hline & 49 & $\begin{array}{l}\text { Standard Oil Co. of Calif. } \\
\text { Kellogg No. } 1\end{array}$ & $\begin{array}{c}\text { Sec. } 20 \\
\text { T.4 S., R. } 10 \text { W. }\end{array}$ & $\begin{array}{c}33.8158 \\
117.9546\end{array}$ & $\begin{array}{c}34 \\
(112) \\
{[\mathrm{df}]}\end{array}$ & $\begin{array}{c}3,118 \\
(10,229)\end{array}$ & $\begin{array}{l}\text { Vaqueros interbedded with Sespe } \\
9,930 \text { to T.D. }\end{array}$ & $\begin{array}{l}\text { West and Redin (1991a); } \\
\text { inspection of conventional core. } \\
\text { Directed hole. }\end{array}$ \\
\hline & 50 & $\begin{array}{l}\text { Standard Oil Co. of Calif. } \\
\text { Pacific Community No. } 1\end{array}$ & $\begin{array}{c}\text { Sec. } 26 \\
\text { T.3 S., R. } 11 \text { W. }\end{array}$ & $\begin{array}{c}33.8754 \\
118.0053\end{array}$ & $\begin{array}{l}24 \\
(80) \\
{[\mathrm{df}]}\end{array}$ & $\begin{array}{c}3,551 \\
(11,651)\end{array}$ & Sespe 11,375 to T.D. & Yerkes (1972, table 6, p. C54). \\
\hline & 51 & $\begin{array}{l}\text { Standard Oil Co. of Calif. } \\
\text { Woodward Comm. No. K-1 }\end{array}$ & $\begin{array}{c}\text { Sec. } 11 \\
\text { T.3 S., R. } 11 \text { W. }\end{array}$ & $\begin{array}{c}33.9223 \\
118.0011\end{array}$ & $\begin{array}{c}75 \\
(245) \\
{[\mathrm{df}]}\end{array}$ & $\begin{array}{c}3,714 \\
(12,184)\end{array}$ & Sespe 11,965 to T.D. & Yerkes (1972, table 6, p. C49). \\
\hline & 52 & $\begin{array}{l}\text { The Texas Co. } \\
\text { Ragan (NCT-1) No. } 1\end{array}$ & $\begin{array}{l}\text { Sec. } 15 \\
\text { T.4 S., R.9 W. }\end{array}$ & $\begin{array}{c}33.8186 \\
117.8047\end{array}$ & $\begin{array}{c}119 \\
(392) \\
{[\mathrm{kb}]}\end{array}$ & $\begin{array}{c}1,734 \\
(5,690)\end{array}$ & 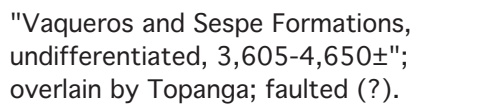 & $\begin{array}{l}\text { Schoellhamer and others (1981, } \\
\text { p. D79). }\end{array}$ \\
\hline & 53 & $\begin{array}{l}\text { The Texas Co. } \\
\text { Ruff No. } 1\end{array}$ & $\begin{array}{c}\text { Sec. } 1 \\
\text { T.3 S., R.10 W. }\end{array}$ & $\begin{array}{c}33.8505 \\
117.8712\end{array}$ & $\begin{array}{c}62 \\
(204) \\
{[\mathrm{kb}]}\end{array}$ & $\begin{array}{c}2,590 \\
(8,497)\end{array}$ & $\begin{array}{l}\text { Sespe } 8,057 \text { to T.D.; overlain by } \\
\text { Topanga. }\end{array}$ & $\begin{array}{l}\text { Schoellhamer and others (1981, } \\
\text { p. D80). }\end{array}$ \\
\hline & 54 & $\begin{array}{l}\text { Union Oil Co. of California } \\
\text { Chapman No. } 29\end{array}$ & $\begin{array}{l}\text { Sec. } 29 \\
\text { T.3 S., R.9 W. }\end{array}$ & $\begin{array}{c}33.8776 \\
117.8449\end{array}$ & $\begin{array}{c}89 \\
(293) \\
{[\mathrm{kb}]}\end{array}$ & $\begin{array}{c}3,199 \\
(10,496)\end{array}$ & $\begin{array}{l}\text { "Vaqueros and Sespe Formations, } \\
\text { undifferentiated, 9,128-T.D."; } \\
\text { overlain by Topanga. }\end{array}$ & $\begin{array}{l}\text { Durham and Yerkes (1964; table } \\
\text { 4, p. B53). }\end{array}$ \\
\hline & 55 & $\begin{array}{l}\text { Union Oil Co. of California } \\
\text { Olive Community No. 4-1 }\end{array}$ & $\begin{array}{c}\text { Sec. } 8 \\
\text { T.4 S., R.9 W. }\end{array}$ & $\begin{array}{c}33.8324 \\
117.8510\end{array}$ & $\begin{array}{c}64 \\
(209) \\
{[\mathrm{df}]}\end{array}$ & $\begin{array}{c}1,291 \\
(4,236)\end{array}$ & $\begin{array}{l}\text { Vaqueros interbedded with Sespe } \\
4,160 \text { to T.D.; "Norwalk fault" at } \\
4,160 \pm .\end{array}$ & $\begin{array}{l}\text { Schoellhamer and others (1981, } \\
\text { p. D81). }\end{array}$ \\
\hline & 56 & $\begin{array}{l}\text { Union Oil Co. of California } \\
\text { O'Neill No. } 1\end{array}$ & $\begin{array}{l}\text { Sec. } 30 \\
\text { T.7 S., R.7 W. }\end{array}$ & $\begin{array}{c}33.5358 \\
117.6432\end{array}$ & $\begin{array}{c}113 \\
(372) \\
{[?]}\end{array}$ & $\begin{array}{c}1,378 \\
(4,520)\end{array}$ & $\begin{array}{l}\text { Vaqueros-Sespe } 2,950 \pm \text { to T.D.; overlain } \\
\text { by Topanga. }\end{array}$ & Vedder (1975). \\
\hline$\underline{\omega}$ & 57 & $\begin{array}{l}\text { Western Gulf Oil Co. } \\
\text { Diamond Bar No. } 1\end{array}$ & $\begin{array}{c}\text { Sec. } 28 \\
\text { T.2 S., R.9 W. }\end{array}$ & $\begin{array}{c}33.9698 \\
117.8311\end{array}$ & $\begin{array}{c}336 \\
(1,102) \\
{[?]}\end{array}$ & $\begin{array}{c}2,081 \\
(6,828)\end{array}$ & $\begin{array}{l}\text { Sespe } 5,700 \pm \text { to T.D.; overlain } \\
\text { by Topanga. }\end{array}$ & $\begin{array}{l}\text { Durham and Yerkes (1964, table } \\
\text { 4, p. B55). }\end{array}$ \\
\hline
\end{tabular}




\begin{tabular}{|c|c|c|c|c|c|c|c|}
\hline 57 & $\begin{array}{l}\text { Western Gulf Oil Co. } \\
\text { Diamond Bar No. } 1\end{array}$ & $\begin{array}{c}\text { Sec. } 28 \\
\text { T.2 S., R.9 W. }\end{array}$ & $\begin{array}{c}33.9698 \\
117.8311\end{array}$ & $\begin{array}{c}(1,102) \\
{[?]}\end{array}$ & $\begin{array}{c}2,081 \\
(6,828)\end{array}$ & $\begin{array}{l}\text { Sespe } 5,700 \pm \text { to T.D.; overlain } \\
\text { by Topanga. }\end{array}$ & $\begin{array}{l}\text { Durham and Yerkes (1964, table } \\
4, \text { p. B55). }\end{array}$ \\
\hline \multicolumn{8}{|c|}{ Northwest sector, figure 4} \\
\hline 58 & $\begin{array}{l}\text { Bell, J. A., Operator } \\
\text { Tapo No. } 71 \mathrm{X} \text { orig. hole } \\
\text { and deepening }\end{array}$ & $\begin{array}{c}\text { Sec. } 14 \\
\text { T.3 N., R.18 W. }\end{array}$ & $\begin{array}{c}34.3504 \\
118.7288\end{array}$ & $\begin{array}{c}652 \\
(2,139) \\
{[\mathrm{kb}]}\end{array}$ & $\begin{array}{c}2,252 \\
(7,389)\end{array}$ & $\begin{array}{l}\text { Sespe, } 3,255 \text { to TD; overlain } \\
\text { unconformably by Calabasas Fm. } \\
\text { (Luisian). }\end{array}$ & $\begin{array}{l}\text { California Division of Oil, Gas and } \\
\text { Geothermal Resources files; } \\
\text { operator well summaries. }\end{array}$ \\
\hline
\end{tabular}

1 San Bernardino Base and Meridian

2 Depth datum: kb, rt, df, gr = kelly bushing, rotary table, derrick floor, ground level, respectively.

\section{APPENDIX 3}

Petroleum exploration drill holes that provide critical insights about the regional extent and history of Vaqueros and/or Sespe strata without encountering either formation

\begin{tabular}{|c|c|c|c|c|c|c|c|}
\hline $\begin{array}{l}\text { Map } \\
\text { symbol }\end{array}$ & $\begin{array}{c}\text { Lease name \& well } \\
\text { number }\end{array}$ & $\begin{array}{c}\text { Section } \\
\text { Township, Range } \\
\text { (S. B. B. \& M.) }{ }^{1}\end{array}$ & $\begin{array}{l}\text { Latitude (N.) } \\
\text { Longitude (W.) } \\
\text { (degrees) }\end{array}$ & $\begin{array}{l}\text { Elevation } \\
\mathrm{m}(\mathrm{ft})^{2}\end{array}$ & $\begin{array}{l}\text { Total depth } \\
\mathrm{m}(\mathrm{ft})\end{array}$ & $\begin{array}{c}\text { Drill depths of stratigraphic } \\
\text { boundaries, feet }\end{array}$ & $\begin{array}{l}\text { Sources of information and } \\
\text { comments }\end{array}$ \\
\hline
\end{tabular}

Northwest sector, figure 4

Seedorf (1983, Fig. 6); also see Shields (1978, Fig. 2) and California Division of Oil and Gas

\begin{tabular}{|c|c|c|c|c|c|c|c|}
\hline 59 & $\begin{array}{l}\text { Shell Oil Co. } \\
\text { Schonfeld No. } 1\end{array}$ & $\begin{array}{l}\text { Sec. } 30 \\
\text { T.2 N., R. } 16 \text { W. }\end{array}$ & $\begin{array}{c}34.2286 \\
118.6040 \\
\end{array}$ & $\begin{array}{c}283 \\
(928) \\
{[\mathrm{df}]}\end{array}$ & $\begin{array}{r}1,573 \\
(5,162) \\
\end{array}$ & $\begin{array}{l}\text { "Topanga Fm." rests on Eocene at about } \\
2,000 \text {. }\end{array}$ & $\begin{array}{l}\text { California Division of Oil and Gas } \\
\text { files for alternative } \\
\text { interpretations. }\end{array}$ \\
\hline \multicolumn{8}{|c|}{ Palinspastic reconstruction, figure 7} \\
\hline 60 & $\begin{array}{l}\text { Union Oil Co. of California } \\
\text { Union-Signal-Texam U-19 } \\
\text { No. } 1\end{array}$ & $\begin{array}{c}\text { Sec. } 35 \\
\text { T.1 S., R.14 W. }\end{array}$ & $\begin{array}{c}34.0424 \\
118.3097\end{array}$ & $\begin{array}{c}62 \\
(203) \\
{[\mathrm{gr}]}\end{array}$ & $\begin{array}{c}1,678 \\
(5,506)\end{array}$ & $\begin{array}{l}\text { "Albite and oligoclase-epidote } \\
\text { amphibolites" (Sorensen, } 1985 \text {, } \\
\text { p. 999) overlain unconformably by } \\
\text { Mohnian of Modelo Fm. }\end{array}$ & $\begin{array}{l}\text { Yeats (1973, p. 134) } \\
\text { Schneider and others (1996, Fig. } \\
\text { 5). }\end{array}$ \\
\hline
\end{tabular}

1 San Bernardino Base and Meridian

${ }^{2}$ Depth datum: df, gr = derrick floor, ground level, respectively. 